\title{
Enlightenment in the Darkness: The British Prisoner of War School of Navigation, Givet, France, 1805-1814
}

\section{Mark J. Gabrielson}

Pendant la Guerre de la Troisième Coalition, de 1805 à 1814, la prison à Givet (Ardennes) a maintenu une école de navigation pour les prisonniers marins britanniques. Á part quelques rares mentions dans les mémoires des prisonniers de guerre, l'école de Givet n'a pas été décrit dans la littérature jusqu'ici. Ce document montre que l'école pour prisonniers de guerre a fourni une éducation complète aux marins britanniques dans les méthodes avancées, à ce début du XIXe siècle, de résolution de problèmes de navigation. Il montrera également que cette éducation n'était point un exercice académique, elle était utile sur un plan métier-vocation et a produit des avantages professionnels pour ses " diplômés » à leur retour en Grande-Bretagne après-guerre. Un manuel de formation de navigation (un " plan d'apprentissage », ou " livre en chiffres " dans le jargon du début du XIXe siècle) a été créé par un étudiant prisonnier à l'école de Givet - un matelot nommé William Carter. Ce livre en chiffres de Carter offre une fenêtre sur le curriculum enseigné à Givet. Le livre montre que William Carter était capable de résoudre des problèmes pratiques sophistiqués de navigation en haute mer au début du dix-neuvième siècle. L'école de la prison de Givet produit au moins un, probablement d'avantage, d'individus qui sont rentrés en Angleterre en 1814 et 1815 suffisamment accomplis en navigation pratique qu'ils pouvaient ouvrir et faire fonctionner des écoles qui formaient d'autres navigateurs de haute mer. En outre, le programme de Givet a enseigné à William Carter, et vraisemblablement à d'autres étudiants, les techniques de navigation astronomique (comme la détermination de la longitude par les " distances lunaires ») qui restaient utiles dans le service naval et dans la marine marchande pendant quasiment le restant du dix-neuvième siècle.

\section{Introduction}

In the depths of the Napoleonic Wars between France and the Third Coalition (1803-1814), 20,000 to 25,000 subjects of George III were imprisoned in France. ${ }^{1}$ Of

1 Edward Fraser, Napoleon the Goaler (New York, 1914), 1. The precise number of British

The Northern Mariner/Le marin du nord XXV, No. 1 (January 2015), 7-41 
these, roughly 10,000 were British sailors. British prisoners of war (POWs) were held in eleven prisons and fortresses scattered across northern and eastern France. A handful of imprisoned British officers and détenus (civilians caught behind enemy lines) organized a school within the British POW barracks at Givet on the Meuse River in northern France. The prisoner population at Givet was almost entirely made up of British sailors. From late 1805 until the cessation of hostilities in 1814, hundreds of these ordinary seamen, many previously illiterate, were taught reading, writing, and arithmetic. Many also were taught trigonometry, astronomy, and sophisticated nineteenth-century maritime navigation problem-solving methods. The prisoners who were involved met regularly with instructors in class-like settings and followed prescribed curricula. Sailors were provided with teaching aids such as textbooks, blank notebooks (cipher books), and writing and drawing instruments. ${ }^{2}$ The Givet POW school operated without the direct support of the British government and the Royal Navy. However, it was operated by British officers and détenus incarcerated in France, supported by private British philanthropists and philanthropies, and with the knowledge and consent of the French.

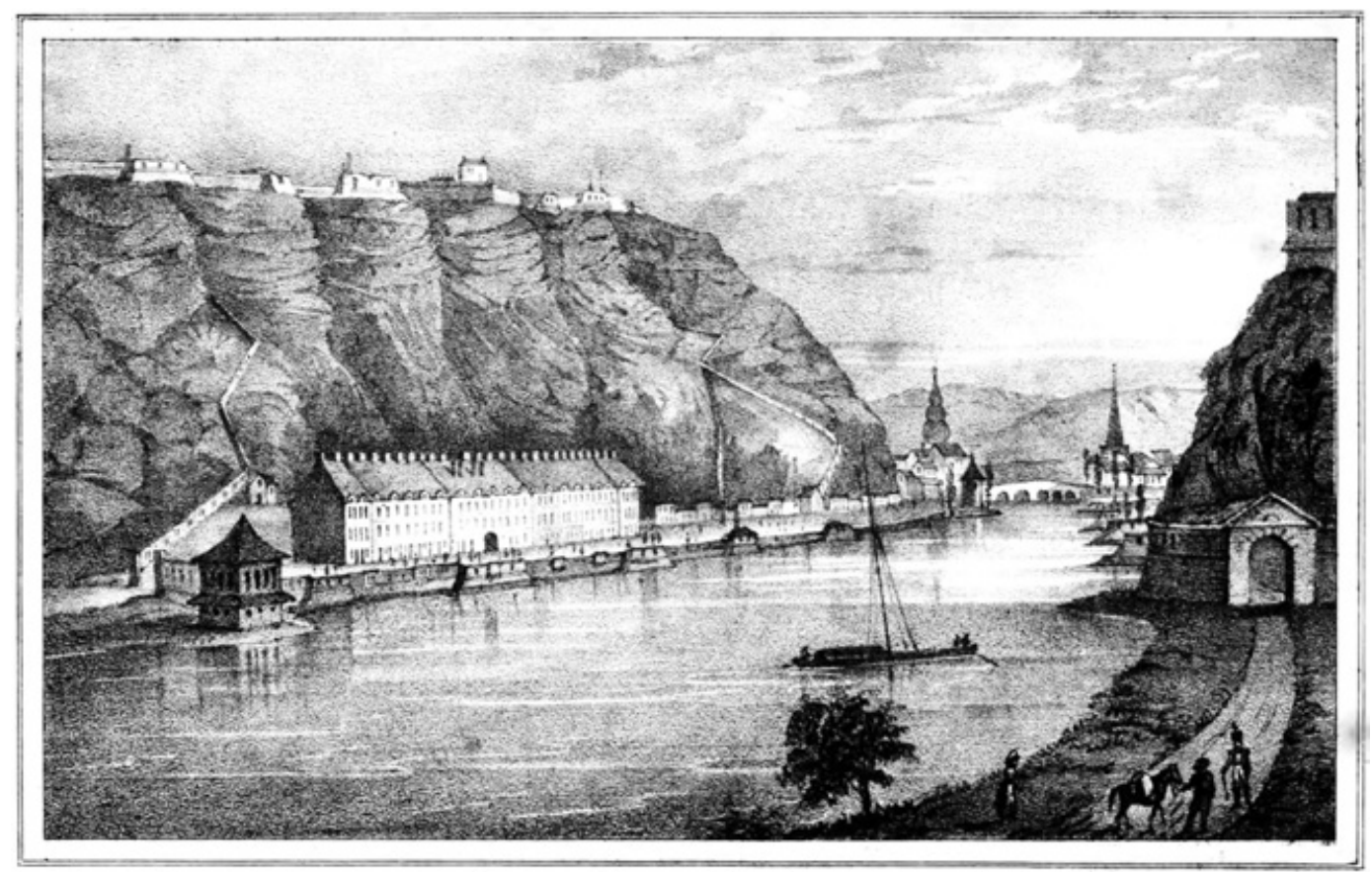

Figure 1: Givet prison barracks on the river Meuse with Charlemont fortress above. Wolfe, English Prisoners of War in France, frontispiece.

maritime (merchant marine and naval) prisoners of war in Napoleonic France is not known. Estimates range from a low of 18,000 to a high of 20,000. There were an additional 2,0005,000 British civilians held as well. See also John Alger, Napoleon's British Visitors and Captives (1801-1815) (New York, 1904).

2 John Tregerthen Short and Thomas Williams, Prisoners of War in France from 1804 to 1814 (London, 1914), 10. 
The navigation education given to ordinary British sailors at the POW school at Givet accomplished two things. First, it conferred a comprehensive education on deadreckoning and celestial navigation problem-solving techniques to ordinary British seamen. Second, it produced "graduates" who returned to Great Britain with vocationally relevant skills useful in the challenging demobilization economy of post-war Great Britain.

There is substantial historiography devoted to the British prisoner experience in France during the Napoleonic Wars. For example, Alger provides a survey of the British POW life based on published prisoner memoirs combined with his observations derived from post-war travel to the most prominent sites where POWs had been held. ${ }^{3}$ His work only mentions the British POW school at Givet in passing. Fraser writes in a similar vein, but primarily examines the behaviors and motives of the Napoleonic government. ${ }^{4}$ Elton relies mostly on prisoner testimony, which focuses almost entirely on dramatic escape attempts and heroic adventures as opposed to the routines of life inside a prison. ${ }^{5}$

More recent scholarship comes closer to the mark but still does not address the focus of this paper. Blake examines how and why sailors were taught religion aboard ship, but does not discuss the pastoral initiatives within POW barracks that may have seeded the school at Givet and elsewhere. ${ }^{6}$ Dickinson fills a gap in the literature by illuminating how British institutions, particularly the Royal Naval Academy (later College) at Portsmouth Dockyards, prepared candidate naval officers at a time when the vast majority was trained under an apprentice system using no recorded curricula. ${ }^{7}$ However, he too does not mention the POW school at Givet.

Publications by prisoners and détenus who returned home and wrote memoirs are more fruitful. Wetherell mentioned the school at Givet, although his editor points out that aspects of Wetherell's accuracy were suspect. ${ }^{8}$ Short and Williams devote several paragraphs in their memoirs to the school. Short claims to have taught navigation to hundreds of his incarcerated countrymen while locked up at Givet. ${ }^{9}$ Other memoirists include the détenus Reverend Robert B. Wolfe and officer POW Captain Jahleel Brenton, both central to the establishment and operation of the school at Givet. However, none of these writers set their POW school experiences within the broader context of the state of navigation knowledge and method in the early nineteenth century, what was taught at Givet, and whether the Givet school "graduates" returned home with vocationally relevant skills.

3 Alger, Napoleon's British Visitors and Captives.

4 Fraser, Napoleon the Goaler.

$5 \quad$ Mrs. Oliver Elton, Locks, Bolts and Bars (Edinburgh, 1947).

6 Richard Blake, Evangelicals in the Royal Navy (London, 2008).

7 H. W. Dickinson, Educating the Royal Navy: Eighteenth and Nineteenth-Century Education for Officers (London, 2007).

8 John Wetherell, The Adventures of John Wetherell, C.S. Forester, ed. (eNet Press, Inc. 2013), 153.

9 Short and Williams, Prisoners of War in France. 
An ordinary British seaman named William Carter was imprisoned at Givet and attended its school. While there he created a cipher book of marine navigation mathematical problems and solutions. ${ }^{10}$ In the book he indicated that he wrote it in $1807 .{ }^{11}$ It is the only known surviving example of written work from a British POW school in Napoleonic France. This artifact is held in the library at the United States Naval War College in Newport, RI and is now the basis of a permanent exhibit at the War College Museum. ${ }^{12}$

\section{Givet Prison}

The prison at Givet was one of eleven POW incarceration facilities scattered across northern and eastern France during the Napoleonic wars. Givet is located in northern-most France, in the Ardennes near the Belgian (at the time called the "French Netherlands") border. It is inland, 200 kilometers from the nearest French seacoast. Inland towns and fortresses were chosen for housing prisoners to discourage escape attempts. The prison system was established by Napoleon to barrack his British, Austrian, Prussian, and later, Russian and Spanish prisoners after the peace of Amiens collapsed in $1803 .{ }^{13}$ Roughly 1,200 British seamen were held at Givet, along with a handful of Austrians, Prussians, and Spaniards. ${ }^{14}$

The town of Givet straddles the River Meuse which flows northwestward out of France, through Belgium, and into the North Sea. Charlemont fortress commands a bluff overlooking the town on the river's left bank. A midshipman captured from a British warship described Givet and its fortress: "Givet", describes Midshipman O'Brien, of the Hussar, "is a fortified town in the Department of Ardennes and Bishoprick of Liege, divided by the Meuse. That portion on the south side of the river is called 'Little Givet.' This town is commanded by a very strong fort and citadel [Charlemont], built upon an immense rock: the fortifications were constructed by Vauban. ${ }^{15}$ A communication between 'Givet' and 'Little Givet' is kept up by means of a pontoon bridge.... Some fifteen hundred prisoners was the normal establishment at Givet..."16

The prison population at Givet consisted almost entirely of ordinary seaman captured from British warships and merchant vessels. Unlike their officers and civilian

10 William Carter, William Carter's Navigation Book, Givet Prison, France, 1807, Naval Historical Collection, Naval War College Library, Newport, RI.

11 Carter, Navigation Book, 28R.

12 Mark J. Gabrielson and John B. Hattendorf, United States Naval War College Museum, Newport, RI. On display beginning October 2014.

13 Fraser, Napoleon the Gaoler, 1.

14 Short and Williams, Prisoners of War in France, 11. Also, Wolfe mentions the other nationalities at Givet in his memoirs, English Prisoners in France, 129.

15 Sebastien Le Prestre de Vauban (1633-1707) was a French fortifications engineer. See www.fortified-places.com. Accessed 10 January 2014.

16 Quoted in Fraser, Napoleon the Gaoler, 60. 
prisoners, ordinary seamen were locked up with little or no prospect of exchange. Ordinary seamen ("ratings" in Royal Navy parlance) were not subject to parole. Parolees enjoyed limited freedoms in exchange for signing a pledge of honor not to escape. An attempt to do so was considered "discreditable" - evidence of a deficient character, both in France and at home in England. Writing forty years after the end of the Napoleonic Wars, the editors of the Chamber's Journal reflected on the parole system:

Officers, and civilians entitled to rank as gentlemen, were allowed to reside on parole within assigned limits and on certain conditions.... One French prisoner [in England] of high rank...was... an honoured guest of the Duke of Devonshire...and...he is said to have declared that the happiest period of his life was when he was a prisoner on parole in England... From 1803 to 1814, several hundreds of French commissioned officers broke their parole, and escaped from England. The number of English officers who acted in a similarly discreditable manner, was proportionately much smaller. The common soldiers and sailors were of course not admitted to parole, but were confined to barracks and prisons... ${ }^{17}$

Paroled British officers and civilians also occasionally were exchanged for French officers and civilians held in England, provided they agreed to never fight

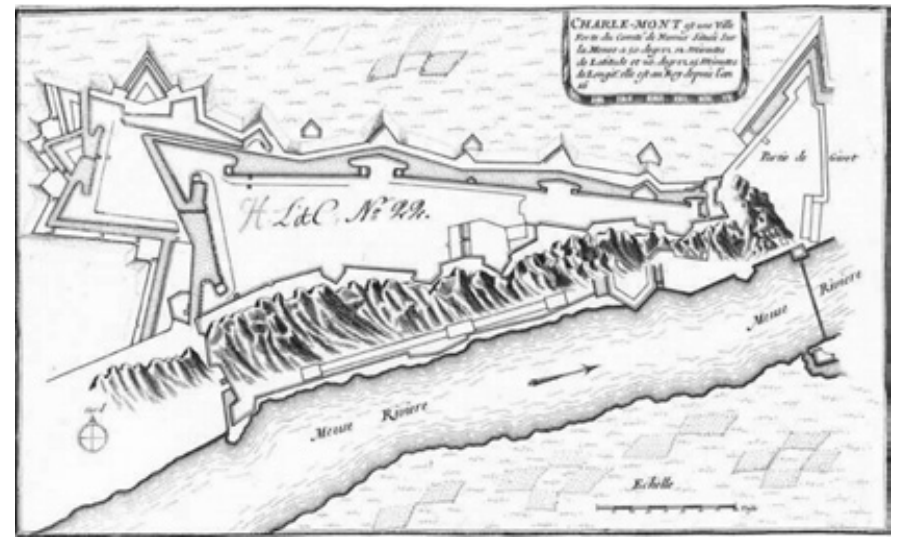

Figure 2: Plan of Charlemont fortress and barracks at Givet circa 1805. Courtesy http://www.fortified-places.com against France again. They therefore had a hope of returning home before war's end. Soldiers, ratings, and midshipmen were not subject to these possibilities, so escape was their only means of getting home early. Many tried, most failed, and some died in the attempt.

Getting to Givet was very difficult for both officers and ratings. The editors of the Chamber's Journal again reflected on

the experiences of the British POWs:

Owing to the distance of most of the depots from the coast, the journey of the prisoners often occupied many days, and was accompanied by every species of hardship. Moreover, the gendarmes were nearly always severe, often brutal, in the exercise of their powers... Prisoners...who were aged or of weekly [sic] constitution, or wounded and broken-spirited, were soon released from their sufferings by death... From one cause or another, all classes of prisoners were liable to be suddenly removed to a different, and often very distant, depot, which was a severe punishment

17 William and Robert Chamber, Chamber's Journal of Popular Literature, Science and Arts, Ser. 3. vols. 1-2 (1854), 331. 
in itself, owing to the hardships invariably endured en route. Many prisoners died on the way during these removals. ${ }^{18}$

British Captain (later Vice Admiral, Sir) Jahleel Brenton, instrumental in the founding and operation of the navigation school at Givet, was captured early in the War of the Third Coalition after the ship he commanded, HMS Minerve (40), foundered on a reef off the coast of France. When war broke out in the spring of 1803, Brenton had taken Minerve into action but was wrecked in a fog off Cherbourg in Brittany on 2 July. He and his crew survived but were captured by French coastal defense forces. ${ }^{19}$ Brenton confirmed that the march inland was long and difficult. In addition to the cold and distances, the prisoners were given only a small allowance by their captors and had to rely on the cut-throat "generosity" of the civilians they passed in order to feed themselves. Brenton gave an example:

After marching during the whole of a tempestuous day, they reached Rem, where they were to remain for the night, and were shut up in a ruined roofless chapel. ${ }^{20} \mathrm{~A}$ small quantity of straw thrown upon a broken pavement, was in a short time soaked with rain; and each man having received his three sols, ${ }^{21}$ had no other means of procuring food than purchasing it at the door, from persons who flocked there with wretched spirituous liquors, and boiled liver. The spirits were of course preferred, and the money intended for their supper was expended in the purchase, leaving the wretched prisoners no other support than their allowance of bread. ${ }^{22}$

After a five months-long march across France in the autumn and early winter, Captain Brenton and his men reached Verdun in December 1803. Brenton wrote about the colorful collection of British inhabitants at Verdun in his memoirs:

The officers in the meantime were permanently settled at Verdun, to which place all the English détenus, from every part of France, were assembled; forming perhaps one of the most extraordinary groups of character, that had ever been collected in the same spot. There were many highly respectable, and exemplary persons; some of whom had been traveling in France for their pleasure, some for the purpose of

18 Ibid., 332.

19 Henry Raikes, ed. Memoir of the Life and Services of Vice Admiral Sir Jahleel Brenton, Baronet, K.C.B. (London, 1846), 144.

20 "Rem" may refer to Remy, a town in Picard north of Paris. Remy is located about 320 kilometers east of Cherbourg and approximately 175 kilometers southwest of Givet.

21 A "sol" was a unit of French currency of little value that was in circulation until 1803 when the French introduced the Franc. From 1720 to 1803 the principal unit of currency was the "Louis d'argent," with approximately 20 sol in one "Louis." However, in March 1803, the same year that Brenton and his men were captured, the French introduced the franc, with 20 sol per franc. It is unclear whether Brenton is referring to the new or old coinage in his discourse. In 1803, 3 sol were worth about 3 pence. In today's currency, 3 pence are worth approximately \$2.94 in purchasing power. See William A. Shaw, The History of Currency: 1252 to 1894 (London, 1896), 414, and www.uwyo.edu/numimage/currency.htm. Accessed 10 January 2014.

22 Raikes, Memoir, 174. 
educating their children and some for economy. There were others, whose sole object was curiosity, or dissipation. There were many skilful [sic] artificers, who had brought their talent to the French market, and were engaged in setting up manufactures, that might rival or surpass their own country. There were many, who from seditious conduct, and republican principles, had found it necessary to take shelter in France. There were fraudulent bankrupts, and broken tradesmen. There were many who had fled from their creditors, and even some who had fled from the gallows. With this motley assemblage the prisoners of war were involved, enveloped in one measure, subject to the same proscription, and the same parole. The amalgamation was not very favorable to the latter, particularly the younger branches of the service. Much good was done, and some striking instances of conduct highly honourable to Great Britain occurred; but all know the influence of bad example, and how easily it captivates the unwary. ${ }^{23}$

In contrast with the rigid social hierarchy at home in Great Britain, Napoleon's British prisoners, people with vastly different backgrounds and positions, were forced to live in social and physical proximity. An interesting question is whether the thousands of King George III's subjects who had lived together and regularly crossed social boundaries in France impacted the trajectory of British public attitudes and policy upon their return to England?

Among the détenus at Verdun was another man who would be important in the development and operation of the navigation school at Givet. The Reverend Robert B. Wolfe, a clergyman of the Church of England, was arrested by French authorities in 1803 while living at Fontainebleau near Paris. Wolfe, clearly a nonbelligerent, and many other British civilians, were held at Verdun due to a the French government had taken the unusual step of declaring in 1803 that all British subjects then in France were prisoners of war. In a footnote on the subject within Wolfe's memoirs, Brenton wrote:

Previous to the French revolution, it was invariably the custom amongst European belligerents, that noncombatants, viz. captains of merchantmen, surgeons, pursers, and all others in a civil capacity, should not be considered as prisoners of war, although taken in battle; but be released and sent home to their respective countries. ${ }^{24}$

Wolfe himself characterized the imprisoning of civilians caught in France as "an exercise of tyrannical power, over individuals who have thrown themselves upon the good faith of a government..." 25 Like Captain Brenton, Wolfe and his family became prisoners, and were transferred to Verdun where most of the captured British officers and détenus were located. Reverend Wolfe, ${ }^{26}$ after obtaining the necessary approvals from the French authorities, led regular worship services in a vacant government building

23 Ibid., 179.

24 Rev. Robert B. Wolfe, English Prisoners in France, Containing Observations on Their Manners and Habits, Principally With reference to Their Religious State, During Nine years' Residence in the Depôts of Fontainebleau, Verdun, Givet and Valenciennes (London:, 1830), 2.

25 Ibid., 2.

26 Raikes, Memoir, 188. 
that had been the chapel in an abandoned convent. ${ }^{27}$

Within a week of the Minerve's crew arriving at Verdun, the French separated the ordinary seamen and midshipmen from Brenton and the other officers, and then marched the sailors off to Givet, an additional 145 kilometers to the north in the Ardennes mountains. Separating officers from their crewmen was customary under Napoleonic France prisoner of war policy. Fraser wrote: "They arrived without their officers, Captain Brenton and his Lieutenants having been held back among the prisoner-officers at Verdun, in accordance with a harsh and unnecessary regulation of the French War Office, which caused much suffering and hardship among the men." 28 The reasons for the "suffering and hardship" were at least two-fold. First, officers often were a source of funds or loans for crewmen who generally were penniless when captured. For example, on several occasions during the march to Verdun, Captain Brenton arranged lines of credit for himself (in one case, in the amount of $£ 2,000$, according to his memoirs) in order to provide funds he could pass on to his crewmen. At one point on the march Brenton attempted to sell his timepiece to raise funds needed to provide a meal for his men. ${ }^{29}$ In addition, charities in Britain established to aid POWs sent money to the officers in France for further distribution to needy cases. In eighteenth- and early nineteenth-century Britain it would have been unheard of to send money directly to the ordinary seamen, midshipmen, and soldiers. Captain Brenton himself wrote:

Well aware that by putting any sum into the hands of the seamen, it might, in many instances, occasion intoxication and improper conduct; and that by providing clothing only, without adding to their allowance of provisions, I should have defeated his Majesty's most gracious intentions of succouring his distressed subjects, as their clothes would have been sold to supply their wants... ${ }^{30}$

As one would expect, with the exception of a few unusually altruistic men like Captain Brenton, often funds never went beyond the British officer corps. Since the French War Office separated British officers from ordinary sailors, usually by hundreds of kilometers, it was difficult or impossible to forward relief funds to places like Givet anyway. While the French government provided some additional financial sustenance to POWs, the meager allowance combined with corruption and outright theft throughout the money distribution system meant that only a portion of the French allocations reached the ordinary seaman.

If they could get it, ordinary seaman prisoners were allowed by the French Government three sols a day. Officers and midshipmen fared much better. According to memoirist Captain Edward Boys, the following monthly allowances (subject to a twentyfive percent withholding by the French gendarmes) went to the more senior prisoners:

Ibid., 188.

Fraser, Napoleon the Gaoler, 61.

Wolfe, English Prisoners in France, 10.

Raikes, Memoir, 181. 


\begin{tabular}{|l|l|l|l|}
\hline Rank & f & s. & d. $^{31}$ \\
\hline Colonels and Post Captains & 4 & 0 & 0 \\
\hline Majors and Commanders & 3 & 0 & 0 \\
\hline Captains (Army) and Lieutenants (Navy) & 2 & 0 & 0 \\
\hline Lieutenants (Army), Clergymen and Pursers & 1 & 10 & 0 \\
\hline Midshipmen, Ensigns, Warrant Officers and Merchant Captains & 1 & 5 & 0 \\
\hline Ordinary seamen & 0 & 7 & 6 \\
\hline
\end{tabular}

Table 1: French fund allowances to British Prisoners by Rank. ${ }^{32}$

Clearly under French law officers were treated far better than ordinary seamen and sailors.

The second reason for their hardship was that naval seamen, many of whom had gone to sea (voluntarily or involuntarily) at a very young age, had grown accustomed to the regularity and discipline of life about a Royal Navy warship like Brenton's Minerve. When released from that tightly controlled environment, whether as prisoner or on leave, naval seaman had a well-deserved reputation for dissipation. Brenton himself explained: "So true it is, that seamen even of experience, and of sterling abilities in the exercise of their profession, are but children of a larger growth when on shore; and hence arises the necessity for that rigorous superintendence, so much blamed by those who are ignorant of the sailor's character." ${ }^{33}$ This unsupervised and destitute crew of British sailors arrived at Givet late in December 1803.

Napoleon's military prison system was segmented into district commands. Both Givet and Verdun were in the Meuse district under a General Monleau. ${ }^{34}$ The first commandant at Givet was Captain Petervin ${ }^{35}$ (both Wolfe and Short refer to him as "Peytavin"). At Verdun the commandant was an officer (referred to by Alger as a General) named Wirion. ${ }^{36}$

Petervin was commandant at Givet from the time the Minerve crew arrived until the autumn of 1804 when he was transferred elsewhere. He was replaced by a second commandant who is unnamed in the memoirs. In 1810 a third commandant arrived, most probably Petervin returning for a second tour. ${ }^{37}$ Throughout Wolfe's ministry at Givet the

$31 £$ sd (pounds sterling, shillings and pence, Latin librae, solidi, and denarii); twelve pence per shilling, twenty shillings per pound.

32 Edward Boys, Narrative of a Captivity and Adventures in France and Flanders between the Years 1803 and 1809 (London, 1827), 41.

33 Raikes, Memoir, 178.

34 Fraser, Napoleon the Gaoler, 75.

35 Ibid., 63.

36 Alger, Napoleon's British Visitors, 203.

37 Wolfe, English Prisoners in France, 101. 
commanding engineer at Givet was a Colonel Flayelle. ${ }^{38}$

Petervin was an accommodating man with whom Brenton was able to engage in "friendly co-operation." 39 However, his less cooperative successor was in command when Wolfe arrived in 1805, and Wolfe referred to him as "our treacherous Commandant." 40 Fraser wrote: "The second Commandant proved to be a harsh tyrant of the Wirion stamp and a dishonest official, with the result that the depot became a regular hell for the unfortunates kept there..."41

Characterizing the second Givet Commandant as "of the Wirion stamp..." was acute criticism indeed. General Wirion regularly blackmailed the wealthier British prisoners at Verdun, amassing as much as $£ 30,000$ in "taxes" and bribes. ${ }^{42}$ When Napoleon appointed a new minister of war (Henri Clarke) in 1810, Wirion was summoned to Paris to answer for his reported corruption. Instead of facing a court martial, Wirion committed suicide in the Bois du Boulogne on 7 April 1810. ${ }^{43}$

From their arrival in December 1803 until the end of 1804, the prisoners at Givet seemed well situated under the accommodating Petervin. After a brief but uncomfortable stay in the fortress dungeons, they were installed in new barracks, which, although crowded and confining, had been equipped by Captain Brenton with beds and firewood. In addition, the French authorities were providing a small sum of money to each prisoner for self-preservation, and through the efforts primarily of Captain Brenton, they received additional monies from England.

Upon Petervin's departure, and the arrival of his unnamed successor, the prisoners' physical and mental conditions deteriorated. Brenton and others at Verdun, including Reverend Wolfe, heard about the difficulties at Givet, possibly through Brenton's clerk W.T. Bradshaw or other correspondents. Wolfe came to the conclusion that his services and abilities would be put to better use at Givet. Brenton and Wolfe worked together to secure the necessary permissions to have the reverend transferred to Givet from Verdun. After the war, Wolfe dedicated his memoirs to Captain Brenton: "it was to your [Brenton's] application that I owed the appointment [to Givet], which suggested to me the thought, and enabled me to obtain the permission, to go to that more active scene of exertion." 44 Wolfe arrived in Givet late in December 1805 accompanied by his wife and young children. In Short's words:

Mr. Wolfe was aware that he must deprive his family of all the advantages which they derived from their residence at Verdun, and subject them to many privations; but

38 Fraser, Napoleon the Gaoler, 77.

39 Ibid., 63.

40 Wolfe, English Prisoners in France, 101.

41 Fraser, Napoleon the Gaoler, 64.

42 Edward Boys, Narrative of a Captivity and Adventures in France and Flanders between the Years 1803 and 1809 (London, 1827). 47.

43 Alger, Napoleon's British Visitors, 203.

44 Wolfe, English Prisoners in France, vi. 
the reports which he continually received of the state of the British seamen at Givet determined him, in the spirit of self-sacrifice, to take up his residence amongst them. $^{45}$

Wolfe noted the bad condition of the men and their circumstances, significantly deteriorated from how Captain Brenton had left them ten months earlier:

On my arrival at Givet, I soon discovered, that I had undertaken a task of much more difficulty and danger, than I had at all been willing to believe. Both in a moral and physical point of view, it would be difficult to conceive anything more degraded and miserable... The barracks were situated in a narrow pass, between the perpendicular rock... and the river Meuse... and all the space the men had for exercise, was between the building itself and the river, along the side of which was a wall. This slip of ground, not more than ten paces in width, and exposed to the southern sun, was, in the heat of summer, a complete oven....In the hospital, the sick were...in a shocking state of neglect, and covered with vermin. Not a single prisoner was allowed to go out into the town....It was almost impossible for any of them to get anything from their friends, for there was no one to receive it for them; and the little that did come, was subjected to a deduction of five percent by the marechal des logis. ${ }^{46}$

Wolfe had found that the men had gambled away most of their money, and what was left they spent on drink. Due to corruption within the gendarmerie and their own vices, the men were reduced to wearing rags and scrounging for leavings in the garbage the French threw into the prison yard. Furthermore, in the first two years of his mission, Wolfe feared for his own security given the backlash against clergymen underway in France at the time. He wrote: "In addition to these discouragements, connected with the field of labour which I had undertaken, I soon found, that there were difficulties in my own situation, which would, probably, involve me in personal danger of a very serious nature; or at least, cause me to be sent away to the dungeons of Bitche." ${ }^{47}$

Wolfe established his ministry and prison school under these difficult circumstances and conditions.

Reverend Wolfe and his family remained at Givet for nearly six years until sent home by Napoleon himself in November $1811 .{ }^{48}$ Occasionally Captain Brenton would visit, and was a constant advocate with the French authorities on behalf of Wolfe's mission. During that time a man like John Tregerthen Short was educated to the point that when he finally returned to England, he could open their own schools of navigation. Wolfe and his school also educated a common seaman like William Carter such that he could produce a book that rivaled the achievements of the privileged students who worked under ideal conditions at the Royal Naval Academy at home in England.

\footnotetext{
45 Short, Prisoners of War in France, 9.

46 Wolfe, English Prisoners in France, 64.

47 Ibid.

48 Short, Prisoner of War in France, 9.
} 


\section{The Origins of the Prison School at Givet}

The Givet prison school came into existence because three forces converged simultaneously: 1 . The need for such a school was recognized by the Reverend Wolfe, and he had succeeded in establishing prison schools elsewhere in the prior year; 2. Wolfe had an energetic and influential ally in Jahleel Brenton. Brenton was a man of action, had some money, was fluent in French, and was directly responsible for 400 men at Givet; and 3. Between Brenton's resources and funds secured from England, the two men could purchase the requisite materials to enable hundreds of Givet sailors to study navigation and produce work like William Carter's cipher book. In the pithy words of POW John Wetherell: "Givet Prison became Givet University." 49 This chapter discusses each of these three forces, beginning with the two remarkable men involved.

\section{The Reverend Robert B. Wolfe}

According to John Tregerthen Short, the Anglican Reverend Robert B. Wolfe was a native of the village of Stone in Staffordshire, England. ${ }^{50}$ Wolfe was in France with his wife and one child when war between Britain and France resumed in May 1803. When hostilities broke out, the family was sent by the French to the town of Fontainebleau, fifty kilometers southeast of Paris. It was there that Wolfe began his prison ministry, in this case, among the British détenus. Fontainebleau also was where the prison school concept was first hatched and a plan of funding developed. Wolfe wrote:

At an early period of our stay in this town [Fontainebleau], a meeting was held for the purpose of considering the best means of assisting those among the prisoners who were in distress...A subscription was entered into, and Mr. Fiott, of Southampton, kindly undertook the superintendence and distribution of it. Shortly afterward, Mr. Lee, of New College, whose subsequent exertions in behalf of the distressed prisoners are well known, took upon himself, at the request of the subscribers, the management of this relief. In the course of that work of charity, this gentleman discovered that there were many poor children whose education had been sadly neglected. On a proposal of his, I willingly set about to raise a small subscription, for the purpose of providing for their instruction, and undertook the superintendence of it. This small beginning was the foundation of that school establishment, which, afterwards, branched out into all the depôts. Under the management of a School Committee, and afterwards the general Committee of relief, it became most extensively useful, not only to the poor children, but to persons of all ages, and to the naval service itself. For in some of these schools, persons of all ages enjoyed advantages of general education and professional instruction, which might bear a comparison with the best naval seminaries at home. And of this both they themselves and the service, are now reaping the benefit. Some of them have already been distinguished as officers in the navy, and others have done themselves credit in civil departments. ${ }^{51}$

49 Wetherell, The Adventures of John Wetherell, 153.

50 Short, Prisoners of War in France, 34.

51 Wolfe, English Prisoners in France, 5. 
In December 1803, Wolfe, along with his growing family and the other English prisoners, were ordered to march from Fontainebleau to Verdun. ${ }^{52}$ Verdun is nearly 300 kilometers to the west of Fontainebleau. Snow was on the ground. ${ }^{53}$ At Verdun, Wolfe again established a school for détenus children. Fraser wrote:

Mr. Wolfe's sphere of labour was mainly at Givet where...his heroic self-devotion effected what was to all intents a very beneficent miracle. He had, though, before that done good work at Verdun. There, before he left for Givet, Mr. Wolfe and his co-adjutor, Mr. Gorden, set up a school for the children of détenus and sailor-boys taken on men-of-war and merchant-men - lads under fifteen which was the age-limit for English boys permitted to stay at Verdun. The two clergymen kept the school going in spite of strenuous opposition for several months, at the end of which time it was forcibly closed... ${ }^{54}$

Fraser does not explain from what quarter came the "strenuous opposition" to Wolfe and Gorden's school for children of détenus and the ships' boys. However, Jahleel Brenton described the situation in his memoirs. As was customary in British schools, the students were "clothed uniformly in neat jackets and trowsers, [and] were marched to church on the Sunday, but the display proved to be unwise." Apparently the French concluded that marching children was a problem within the détenu community, and by an order from Paris, all of the children at Verdun were separated from their parents and guardians and sent to Sarrelibre, "indeed, it may be said, to the utter ruin of many." 55

By December 1805, with the help of Captain Brenton, Wolfe had secured the position of chaplain for all British prisoners in France, and used the privileges of that appointment to transfer himself and his young growing family north to the barracks on the Meuse.

I was appointed chaplain for British prisoners in France; and this gave me the claim, which, to the great astonishment of everyone, the French government admitted, to choose a depôt, where the prisoners, being confined to the walls of the prison, had the greatest need of the consolations of religion. And Givet, as the first established, and, perhaps, at that time, the most numerous depôt, was fixed upon....I was informed, that the food in that place was bad, and the people still worse... ${ }^{56}$

When Wolfe arrived at Givet he found that the men and their quarters had deteriorated over the ten months since Captain Brenton had visited. An immediate challenge was to establish a working relationship with the newly installed commandant of the prison..$^{57}$

The commandant, and those who were under his orders, from the time I arrived at the

52 When Wolfe was incarcerated in March 1803 he had one child. By the time he and his family were released and left France for England in 1812 he had six children.

53 Wolfe, English Prisoners in France, 27.

54 Fraser, Napoleon the Gaoler, 188.

55 Raikes, Memoir, 188.

56 Wolfe, English Prisoners in France, 60.

57 Ibid., 101. 
depôt, viewed me with a very evil eye. They had all a share in the spoil of the poor prisoners; and my interference on their behalf, and the opportunities which I had of detecting their extortions, enraged them exceedingly against me... These officers were loud in their threats of denunciation, and sending me off to Bitche. ${ }^{58}$

Yet, it seemed that the French had no objection to Wolfe setting up his new school among the prisoners, apparently because it did not interfere with the guards' ability to claim their "share" of monies sent from Paris and England to feed and clothe the prisoners.

As many as five hundred sailors were involved in the school. ${ }^{59}$ Many sailors were taught to read and write. Others were taught the "highest rules in arithmetic." 60 Like William Carter, still others were taught navigation problems and solutions, as well as chart and map-making. Wolfe also wrote that the prisoners fabricated a "form of a vessel," or model, upon which they practiced the "practical part of their profession."61

Wolfe created a faculty out of the prisoner population and paid them small sums to instruct their fellow prisoners in their specialty. Wolfe supported himself and his family with a small allowance from the government, but also by contributions from officers like Captain Brenton, and from the prisoners themselves. Brenton arranged to have Wolfe appointed a chaplain in the navy, which then entitled him to a small prisoner of war allowance from the Transport Board as well. ${ }^{62}$

Wolfe returned to England with his family in January 1812. With the exception of a brief parole at the end of 1811, he and his wife had spent nearly nine years incarcerated in Napoleonic France, six of those at Givet.

Wolfe wrote his memoirs in 1830, and at the end of the dedication (to Brenton), indicated that he was living in "Cranley." 63 There is currently no town named "Cranley" in England. However, there is a "Cranleigh" in Sussex, and a search of death records show that a Robert Barber Wolfe died in that county in December $1843 .{ }^{64}$ There also is a "Cranley Gardens" section of London which is west of the city center. A Robert Wolfe died in "West London" in September 1843. Perhaps this person was our Givet Reverend.

\section{Captain Jahleel Brenton}

Captain Brenton's life is well documented. As a successful naval officer, hero of Givet and Verdun, and a member of the aristocracy, Brenton had a biographer. The modest Reverend Wolfe had none.

Jahleel Brenton was born into a British colonial naval family on 22 August 1770

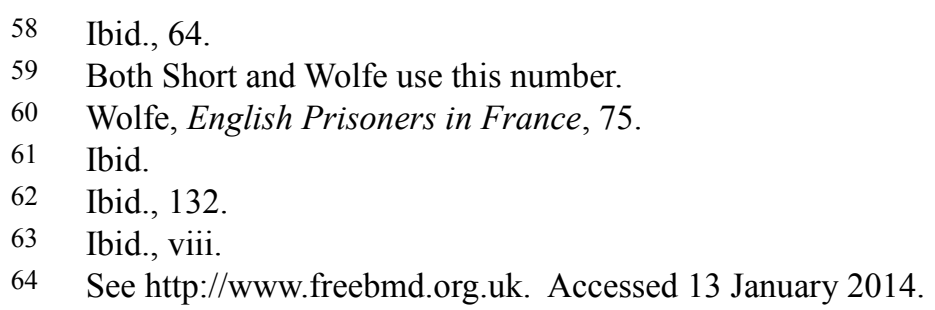




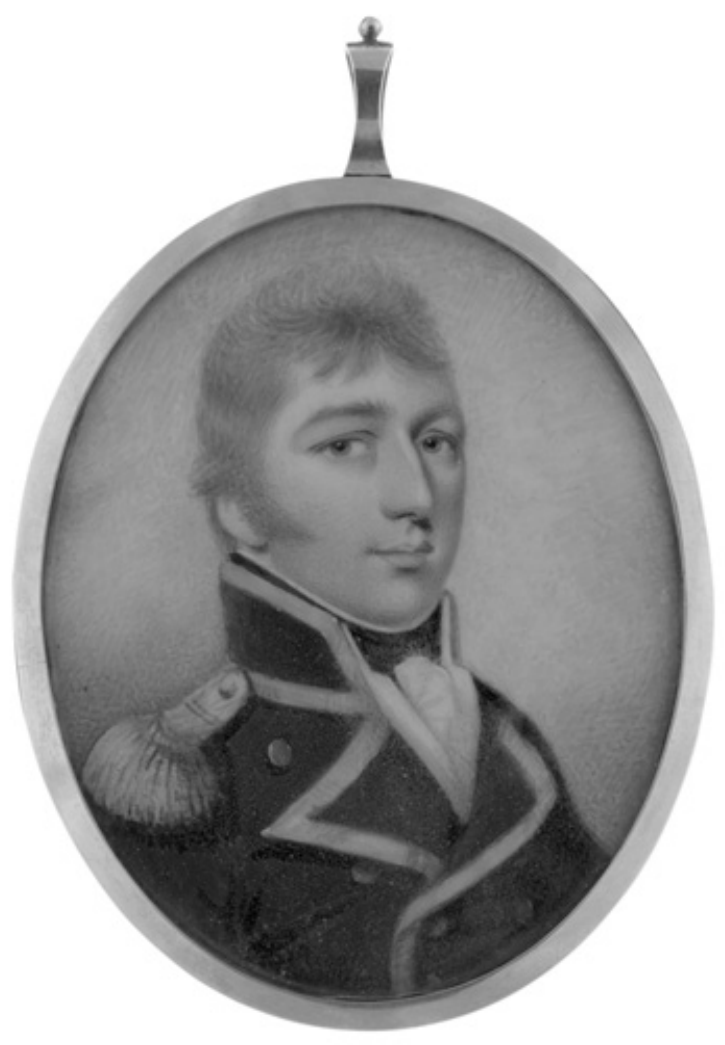

Figure 3:. Captain Jahleel Brenton. Royal Naval Museum Portrait Collection. then, at age 17, Jahleel embarked on HMS Dido to sound and survey the waters and bays of Nova Scotia. It was there that he met his future wife Isabella Stewart whom he married fourteen years later when she visited England with her family.

Jahleel Brenton passed his lieutenancy examination in March 1790, aged twenty. As Britain was not at war in 1790, he had little prospect of employment in the Royal Navy, so he volunteered to serve in the Swedish navy, then in a naval war with Russia.

65 Biographical information for Captain Jahleel Brenton largely is drawn from Raikes, Memoir.

66 Wallace was killed in action off Malta in November 1799 ranked lieutenant. Captain Edward Pelham Brenton, Esq. wrote The Naval History of Great Britain: 1783-1836 (London: Henry Coburn, 1837) as well as a number of papers and treatises on caring for the poor and educating the young in Great Britain. For example, he wrote Observations on the Training and Education of Children in Great Britain: a letter to Sir James Graham on impressment: and a translation from the French of $m$. Ducpetiaux's work on mendicity: with an Appendix. London, 1834. The Making of the Modern World. Web. Accessed 8 January 2014.

67 In Newport, the name Brenton still adorns geographical features. The southern end of Newport Harbor is Brenton cove. The reef extending south from Newport Point is Brenton reef. 
After only a few months service, that conflict ended and Brenton returned to England where he was appointed lieutenant of the sloop HMS Speedy (14), which was tasked with pursuing smugglers. Shortly thereafter he received his first command, the small cutter HMS Trepassey (rating unknown) posted to Newfoundland. He returned to England in 1794 after war broke out with revolutionary France and was assigned as second lieutenant of HMS Sybil (28), a frigate that patrolled the Dutch coast over the winter of 1794-95. Sybil was involved with the evacuation of the British army from the continent in February 1795.

During this period of Britain's war with France, Brenton served as an officer aboard a series of heavy British men-of-war, including HMS Gibraltar (80), Barfleur (90), and Ville de Paris (74). In 1799 he was appointed commander of Speedy on which he had served as lieutenant eight years prior. Speedy was one of the most celebrated small warships in the Royal Navy. Under Brenton's command she had great success in several engagements near the French and Spanish coasts.

In 1800 his achievements in Speedy were noticed by Horatio Nelson who informed Brenton that he was to be promoted to post captain. He was relieved of his Speedy command by the soon-to-be famous Thomas Cochrane (later Lord Sir Thomas) who captained the brig in a series of dramatic victories, including the capture of the larger and more powerful Spanish xebec frigate El Gamo (32) ${ }^{68}$

Brenton's career continued to progress. Captain Brenton was appointed to command the recently captured HMS Generaux (74) and then HMS Caesar (80), Admiral Sir James Saumarez's flagship. His experience in Caesar was important to Brenton in many respects, not least of which was his recognition of the value of a reliable and committed clergyman to the welfare of a crew. His perspective foreshadowed his experience at Givet and his collaboration with the Reverend Wolfe. Brenton wrote in his memoirs:

Perhaps no ship in the British navy had ever enjoyed more comfort and harmony than the CAESAR; and much of this was undoubtedly owing to the conduct of the Chaplain, the Reverend Evan Holiday, who was indefatigable in every part of his duty. And as it is important to shew, how far benefit may arise to a ship's company from the Chaplain's influence, independent of the weekly instruction [Sunday services], to which he is bound by the articles of war to the Sabbath, it may not be amiss to describe Mr. H's system. In the first place his conduct was so correct, and so accordant with is sacred functions, in his intercourse with his messmates, that the same guarded and decorous manners, were preserved by them, whilst he was present in the ward-room, as though a lady had been present... He was most successful also in preventing the infliction of punishment, as well as in preventing the crimes which called for it. No sooner was a man put into the master at arms list as a culprit, than Mr. H. was in communication with him; got at his character, his motives, and the circumstances which had led him to commit the fault. It thus often happened, that he found out such favourable points, as enabled him to recommend the culprit to mercy, 
and to induce the Captain to pardon him... ${ }^{69}$

Brenton returned to England on 19 April 1801, and married Isabella Stewart, daughter of Anthony Stewart of Annapolis, Maryland. The Treaty of Amiens brought a brief period of peace between Britain and France, but war broke out again in 1803 and Brenton took command of HMS Minerve (40). During action close off Cherbourg, France, Minerve ran aground in fog on a lowering tide. After a period of resistance, Brenton recognized the inevitable and on 2 July 1803, surrendered his ship, crew, and himself to French forces. Brenton and his 400 officers and men became prisoners of war. ${ }^{70}$

Brenton distinguished himself during his captivity in France. He was based in Verdun along with other officers and civilians of a "gentlemanly" stature. However, he was not content to stay there. He often traveled to Givet where 400 of the Minerve crew were imprisoned. He also traveled to other depôts. In his memoirs he mentions Sarrelibre and Bitche. His stay in France was marked by some pleasant times, as well. In April 1805 his wife, Isabella, and his two year-old son William were able to come to France and join him at Verdun. Nine months later, on 16 January 1806, Isabella gave birth to a daughter while the family was visiting British détenus in Tours. ${ }^{71}$ By December 1806, Captain Brenton was exchanged for a Captain L'Infernet, commander of L'Intrepide (74), who had been captured at Trafalgar in October $1805 .^{72} \mathrm{He}$ and his family were granted their freedom under the stipulations of parole and they sailed for England.

Brenton's commitment to charity and matters of faith continued after he returned to England and into his later years. His biographer wrote:

Throughout his life Brenton spent time and energy on the work of charitable organizations... During his active career, and in retirement, he developed his interest in the conditions of merchant seaman. His brother Edward Pelham Brenton shared these interests, and together they formed a society for the relief of shipwrecked sailors, and investigated the problems of juvenile delinquency.

To promote these subjects Brenton wrote a number of books and pamphlets: $A n$ Appeal to the British Nation on Behalf of her Sailors (1838), The Hope of the Navy, or, The True Source of Discipline and Efficiency (1839), and Remarks on the Importance of our Coast Fisheries etc. (1843). A Memoir of Captain Edward Pelham Brenton (1842) commemorated his brother's literary achievements and their shared interests. ${ }^{73}$

Brenton's last assignment in the service of his country was as lieutenant-governor of Greenwich Hospital. He retired from the navy in 1840 with the rank of rear-admiral of the Blue and he died on 21 April 1844 of "general debility."74

69 Raikes, Memoir, 125.

70 Fraser, Napoleon the Gaoler, 61.

71 Raikes, Memoir, 264.

72 Ibid., 283.

73 P.K. Crimmin, Oxford Dictionary of National Biography, www.oxforddnb.com. Accessed 20 March 2014.

Ibid. 


\section{Funding for the Givet Prison School}

Funds for the prisoner of war schools in France came from both philanthropies at home as well as from the wealthier prisoners and détenus. ${ }^{75}$ These funds found their way to the Schools Committee at Verdun and were further distributed to the depôts at Fontainebleau, Verdun, and Givet. There were several sources of funds from Britain. One example was specific prisoner relief fundraising appeals in conjunction with entertainment events in London such as the theater or musical performances. ${ }^{76}$ Another was the Lloyd's charities mentioned by Thomas Williams in his memoirs: "Some three or four years after we arrived at Givet we were allowed from the English one penny per day - it was said to be from Lloyd's - and by that addition to our French allowance (although very small) we may safely attribute the saving of us all from starvation." 77

The Lloyd's Patriotic Fund was founded in 1803 and claims to be one of the oldest military charities in the world. ${ }^{78}$ However, according to Brenton, late in 1805 the French government determined that funds would no longer be permitted from England to support the British POWs, and that each host country would henceforth be responsible for supporting its POW population. ${ }^{79}$ Brenton speculates that the reason the French did this was that while the British POWs were "so liberally provided for by their own government," the French had no hope of inducing the men, particularly the Catholic Irish, to desert and fight for the French. What is equally likely is that it was becoming very expensive for the French government to provide funds for their own POWs held in England, which by some estimates outnumbered the British POWs in France four-to-one. Regardless, after 1805 it became increasingly difficult to get money to the prisoners at Givet, but somehow, resourceful men like Brenton and Wolfe managed to do so and to fund and supply their school of navigation.

\section{The William Carter Navigation Journal}

A hand-written and illustrated cipher book of marine navigation mathematical problems and solutions has survived from Givet. It is the only known existing example of written work from a Napoleonic-era British POW school.

Examination of this artifact evokes four sets of historical questions: 1. What is it made of and how was it physically created? 2. Where did it come from and how did it arrive at the Naval War College? 3. What do its contents teach the historian? And, 4. Who created it?

75 Wolfe, English Prisoners in France, 44.

76 For example see: Lines Addressed to the Audience of Drury-Lane Theatre on Tuesday, July 6, 1813 on the Occasion of the Benefit for the British Prisoners in France (London, 1813).

77 Short, Prisoners of War in France, 77.

78 See the Lloyd's corporate website: http://www.lloyds.com/lloyds/corporate-responsibility /charity/patriotic-fund. Accessed 13 January 2014. 


\section{Physical Attributes}

The workbook was created in or around $1807 .{ }^{80}$ It is not known how long it took Carter to create it. As discussed above, the Reverend Robert B. Wolfe arrived at Givet in December 1805 and founded the school shortly thereafter. The gradual, and chaotic, "release" of Napoleon's POWs began late in 1814 as Coalition forces advanced into France from both northwest and southeast. However, with the exception of the notation that the practice Days Work entries are dated "January, 1807," it is not known exactly when Carter began or finished his cipher book.

It is a well-preserved manuscript that is 7.5 inches wide, 9.5 inches long and 0.5 inch thick. It is 116 pages (covers included) in length. Excluding the front and back covers, all but three of the pages are written or drawn upon. The paper stock is heavy by modern standards, and is made from linen and cotton pulp. Numerous horizontal shadings in the paper are visible, likely the result of chain lines resulting from the papermaking process commonly used in the early nineteenth century. ${ }^{81}$ The lines are spaced evenly and are approximately $1 / 8$-inches apart. The binding is constructed of loosely stitched gatherings of approximately twenty leaves each. The cover is heavy pulp board covered by a sheep leather veneer as was standard at the time.

The writers likely used iron gall ink for lines, lettering, and embellishing scrollwork. The writers used colored inks, although in certain of the larger drawings, water colors may have been used. In the early nineteenth century, colored inks were not stable and therefore were very probably sourced locally. The writers used steel-nibbed pens, probably of various gauges given the fineness of some of the images. ${ }^{82}$ The value of the manuscript is unknown.

\section{Provenance}

The William Carter cipher book was donated to the Naval War College on 14 June 1955, by Colonel W. Dennison, Jr., an Air Force officer on the Naval War College staff. The gift was presented in the name of his mother, Mrs. Junius W. Dennison of San Diego, California. Where or how Col. Dennison acquired the manuscript is not known. ${ }^{83}$

Harvard University doctoral candidate John Dixon wrote that blank books such as the one used by Carter were purchased in London for use as working logbooks aboard ships. According to Dixon, in 1776 one such book was purchased for two shillings (one

80 Carter, Navigation Book, 28R.

81 For reviews of papermaking prior to the invention of machine-made paper in the 1830 s see the following: "Papermaking in the 1800s," http://paper.lib.uiowa.edu/european.php . Accessed 2 January 2014; and "History of Papermaking in England," http://baph.org.uk/ukpaperhistory.html . Accessed 2 January 2014.

82 The author is indebted to Leslie Morris, Archivist of Post-1800 documents at Houghton Library, Harvard University for her insights on historical papermaking and binding conventions, as well as pens, inks and color washes used in the early nineteenth century. Interviewed 20 November 2013.

83 Evelyn Cherpak, head, Naval Historical Collection, Naval War College, Newport, Rhode Island. An interesting line of further investigation is to determine how the Carter cipher book came in to the possession of the Dennison family. 
tenth of a Pound Sterling) and each page had a Britannia watermark, a "popular motif among British papermakers." 84

Published books were shipped from England to prisoners in France. For example, the London Bible Society sent Bibles in 1813, although they were confiscated by French officials in Morlaix in Brittany. ${ }^{85}$ However, it was not unusual for the French themselves to provide books to British prisoners. For instance, a Book of Common Prayer was produced for the English prisoners, in English, by French publisher Lewis Christophe in 1810 by order of Napoleon himself. A copy of this book is held in the collection of the Museum of the Royal United Service Institution (Whitehall, London). ${ }^{86}$ However, it is unlikely that the blank notebook used by William Carter came from England.

There is no discernible watermark within the Carter cipher book paper. That suggests the blank book came from a French source as the British government required all producers of paper to put watermarks on each page so that the source could be traced for tax purposes. ${ }^{87}$ It is most probable that the French provided the blank cipher books, or that they were purchased from a local vendor by Wolfe, Brenton, or a designee using funds from the School Committee.

\section{Contents}

Of the book's 116 pages 111 are written and/or drawn upon, the first 106 by Carter and the last five by someone else, presumably another student at the Givet prison school. The final written page also contains some casually written notes in French that appear to be an accounting of food supplies.

The largest number of Carter's pages (97 of the 106) are dedicated to practical navigation problem statements and their solutions. Three pages consist of drawings best described as "folk art." 88 An example of such art, including informative writings by Carter, is shown in figure 4 below. Six pages contain nautical or astronomical constructs. ${ }^{89}$ Ten contain an example log book of an imagined voyage. ${ }^{90}$

The written and drawn content of the cipher book provides important evidence about: 1. William Carter's identity; 2 . What elements of practical navigation were taught at the Givet prison school; 3. How certain navigation problems were expressed and solved in the early nineteenth century; and 4 . What training materials and collaterals were available to the Givet prisoners to support their training. Each of these is discussed below.

84 John Dixon, Untitled PhD paper, "Chapter 1: Are We There Yet? Logbooks as Navigational Instruments, 1775-1800," 1.

85 Fraser, Napoleon the Gaoler, 48.

86 Ibid., 48.

87 John Bidwell, Astor Curator of Printed Books and Bindings, The Morgan Library \& Museum, New York, NY, e-mail 10 January 2014.

88 Carter, Navigation Book, 2L, 2R and 55L.

89 Ibid., 1L, 9R, 22L, 22R and 54R.

90 Ibid., 28R-33L. 


\section{The Cipher Book's Creator}

William Carter identifies himself by name on three separate pages. ${ }^{91}$ The second writer who used the last five pages for instructional purposes also identified himself, John Daniel Banks, but we know nothing more about him from the cipher book. $^{92}$

Givet prison was one of ten prisons in France where ordinary sailors and soldiers were held. ${ }^{93}$ Therefore, it is highly probable that William Carter was an ordinary seaman, or less likely, a midshipman. ${ }^{94}$

The cipher book page shown in figure 4 is highly informative. In the medallion in the upper right corner, Carter wrote: "William Carter. Prest [Pressed] Out of the Earl St. Vincent May 27 1803." Furthermore, he wrote that he created the cipher book, at least in part, during January $1807 .{ }^{95}$ With this

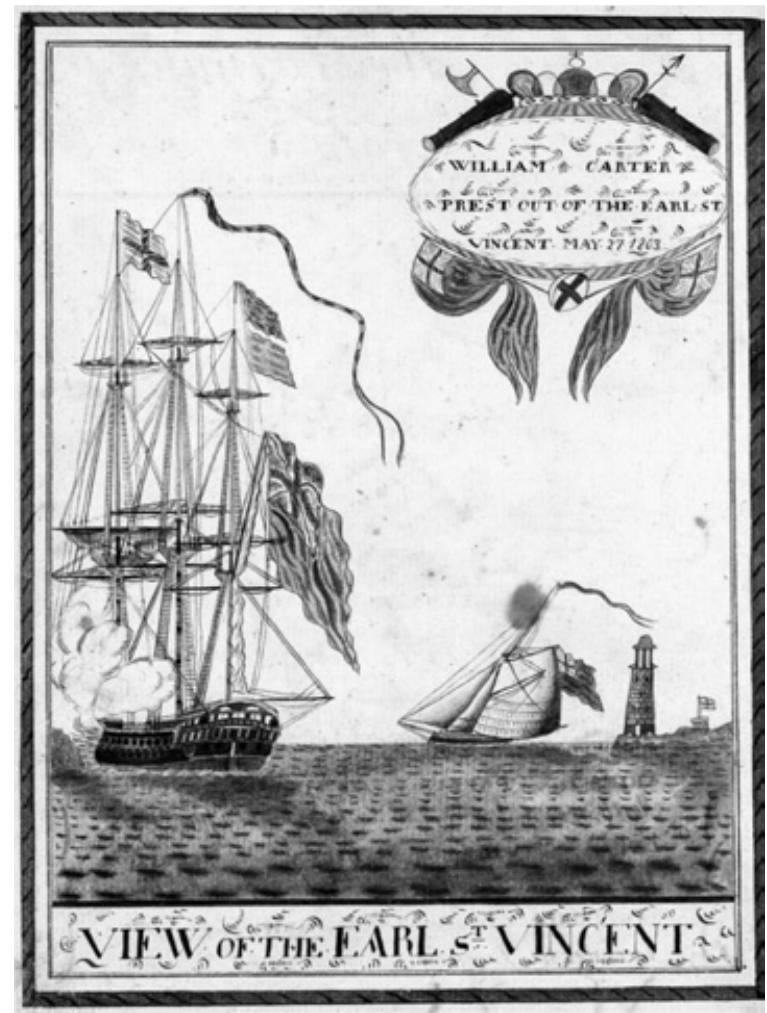

Figure 4:. Scene showing the event of William Carter's impressment. Carter. Navigation Journal. $55 L$. information it is possible to identify this particular William Carter in the service records of Great Britain's Royal Navy with a reasonable degree of confidence.

Data derived from service records at the National Archives in Kew, England, show that there were twenty-two men named "William Carter" imprisoned in France 1805-1815. ${ }^{96}$ Thirteen of these served in the Royal Navy; the remainder were army personnel. Seven of the thirteen naval personnel were imprisoned over a timeframe not

$91 \quad$ Ibid., 3L, 28R and 55L.

92 Ibid., 56R.

93 Raikes, Memoir, 178.

94 There also are no records of an officer named "William Carter" who could have served in the Napoleonic era in the National Archives at Kew. See: http://discovery.nationalarchives .gov.uk/SearchUI/s/res/2?_col=2\&_dt=RN\&_fn=william\&_ln=carter\&_ser=ADM\%20196 . Accessed 13 January $201 \overline{4}$.

95 Ibid., 28R.

96 See www.forces-war-records.co.uk . Accessed 15 December 2012. Data are derived in part from ADM 103, a reasonably comprehensive record of British prisoners of war in France during the Napoleonic Wars. 
before 1803 (when hostilities with France reignited) and inclusive of 1807 when Carter wrote that he created the cipher book. Of those seven, two were officers and therefore not likely to be imprisoned at Givet. Five candidates from these public records remain.

Of these, the most probable author of the Givet cipher book served in HMS Defiance (74), which had a crew of 590 men. ${ }^{97}$ He was rated "landsman" and thus may have had mathematical or graphical training prior to his impressment. He hailed from Cornwall, a county that produced many sailors (as well as many Carters, albeit mostly miners). His hometown of "Cambro" is listed in the Defiance muster book as well. ${ }^{98}$ His service number was SB-411 and he entered the Defiance muster book on 13 August 1803, at age 21. A bounty of $£ 10$ had been paid for his impressment on 10 July 1803, suggesting that he was held prior to his assignment to a particular ship. ${ }^{99}$

In addition to the medallion, other elements within the image in the cipher book portraying Carter's impressment are informative (see figure 4). The ship on the left is a warship as indicated by her guns, the long naval pennant at the masthead and the naval ensign flying from the mizzen mast. This ship is shown firing a gun, probably a shot to command another vessel to heave-to. The warship is a two-decker, consistent with the armament layout of a 74. She flies a red naval ensign showing that she is part of the fleet under the command of an Admiral of the Red, the most senior commander in the fleet. In 1803 the Admiral of the Red was Sir William Cornwallis, also Admiral of the Channel Fleet and charged with defending England's coast from a threatened invasion from France. ${ }^{100}$ Ship service records show that HMS Defiance was re-commissioned in May $1803^{101}$ which corresponds with the log book entry indicating that she lay in Portsmouth at the naval dockyards. ${ }^{102}$ This is the same time that William Carter, author of the cipher book, reports that he was pressed.

\section{An Example Celestial Method Taught at Givet: Using the Position of the Moon in the Sky to Determine Longitude}

Of the ninety-seven pages in the Carter cipher book with solutions to problems, sixteen are dedicated to finding longitude from the moon's position in the sky: "lunars." Of all the problems he solved, from an historical standpoint these are the most interesting.

Astronomers had established lunars as a practical method for accurately

97 ADM 36/16244.

98 There is presently no town named "Cambro" in Cornwall, but there is a significant town in Cornwall now named "Camborne." A William Carter appears in the 1832 Camborne voter rolls.See "Cornwall Online Parish Clerks," http://www.cornwall-opc.org/Records/ parishes/A-D/camborne_voters_1832.php. Accessed 15 January 2014.

99 ADM 36/16241.

100 William Loney, RN. http://www.pdavis.nl/ShowCommanders.php . Accessed 8 January 2014.

101 Royal Museum Greenwich. http://www.rmg.co.uk/upload/pdf/Warship_Histories_Vessels _v.pdf. 2999. Accessed 8 January 2014.

102 ADM 52/3598 
measuring longitude on land as early as the late fifteenth century. The method had been proposed by Regiomontanus, the Latin name for John Muller of Königsberg, as early as $1472 .{ }^{103}$ The German astronomer John Werner published the proposition in $1514 .{ }^{104}$ The challenge for the astronomer was to evolve the method into one that was practical for a moderately well-educated navigator working on a ship at sea. This required three developments. First, the navigator needed an optical instrument sufficiently accurate and robust to reliably measure the angular distances among moon, stars, and horizon on a moving ship (yawing, rolling, pitching, traversing through the water, all in an environment of highly variable temperature and humidity) in the hands of a reasonably competent observer. Second, he required tables of data forecasting the precise distances among the horizon, moon, and selected (bright) stars on each day in the future at a specific location from which longitude would be measured (in Carter's case, the Royal Observatory at Greenwich). Third, he needed to have mastered methods (specifically spherical trigonometric techniques) with which a typical sailing master or navigator could

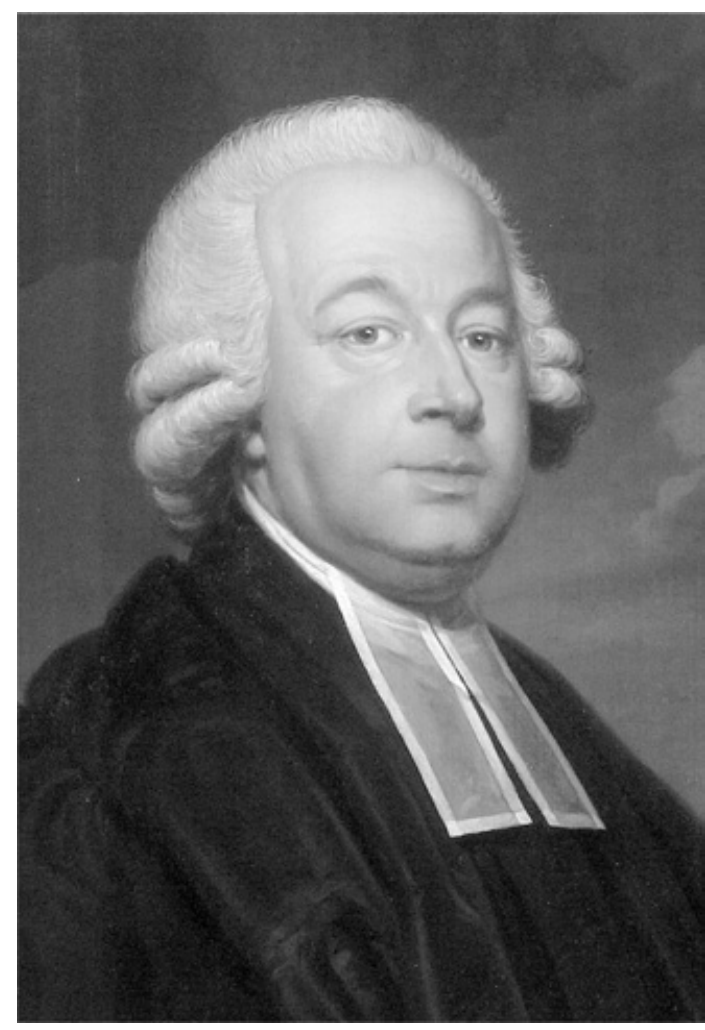

Figure 5: Nevil Maskelyne, Fifth Astronomer Royal. Royal Naval Museum Portrait Collection. repeatedly and precisely complete a mathematical process referred to as "clearing the distance," that is, resolving the complexities of "reducing" a set of observations to a longitude.

When William Carter was a student at the Givet Prison school, these three developments had progressed to the point where longitude determination by lunars was practical for use in oceanic navigation. The instrument was the sextant - accurate, robust, and reasonably inexpensive. Data tables forecasting the precise positions of the sun, moon, and certain stars were published annually, in advance, by the Royal Observatory in Greenwich in The Nautical Almanac. Finally, mathematical methods had been developed and tested that enabled the reasonably well-trained to locate the navigator's ship anywhere on the globe.

In these sixteen pages of the book with solutions for longitude, Carter expressed eight different problems, or "cases," and then proceeded to solve

103 Louis Allen Harding, A Brief History of the Art of Navigation (New York, 1952), 92.

104 E.G.R. Taylor, The Haven Finding Art: A History of Navigation from Odysseus to Captain Cook (New York: Abelard-Schuman, 1957), 188. 
each one using two different methods, both older and more complex methods of finding longitude than the equal altitude method, but in common use in the Royal Navy. For each case he first applied a lunar method developed by British mathematician Israel Lyons, and then he solved the same problem using a method developed by George Witchell, a simplified and more approximate approach. Carter most directly benefited by the work of his nation's Astronomers Royal, in Carter's time Nevil Maskelyne, who directed the publication of the first Nautical Almanac in 1767. The Nautical Almanac is still published today. William Carter and the navigation students at Givet must have had at least one copy of the Nautical Almanac from each of 1796 and $1803^{105}$ given the solutions in his cipher book. ${ }^{106}$

\section{The Givet Navigation Curriculum}

Students at the Givet prison school were taught how to express and solve the most common, and difficult, navigation problems encountered at sea. Their training was practical, not theoretical. Students at Givet had access to at least seven tools based on a close examination of Carter's cipher book. One was a blank cipher book, and as suggested by the last several pages in Carter's book, some may have been used by multiple students. ${ }^{107}$ The second tool was a set of steel-nibbed pens. Third were black iron gall ink and locally produced colored inks. ${ }^{108}$ Fourth were a straight edge (perhaps a Gunter scale) and a set of dividers (or "compass" in lay parlance). These tools (as well as others like an octant not likely available to students at Givet) were illustrated by Carter in his cipher book. ${ }^{109}$ Fifth, in addition to at least the 1796 and 1803 editions of the Nautical Almanac, was a copy of a navigation textbook by John Hamilton Moore. Approximately one half of the 114 problems and solutions (several by multiple solution methods) in the Carter cipher book are drawn directly from this text, most probably the thirteenth edition given the date of its release and exact correspondence of the wording of a number of the problems as in this edition. ${ }^{110}$ The Moore textbook is shown in Carter's drawing, and is mentioned in Thomas Williams's Givet memoirs:

105 Great Britain, Commissioners of Longitude, The Nautical Almanac and Astronomical Ephemeris... (London, 1795 and 1802).

106 Carter, Navigation Book, 44L. This page shows a 1796 scenario whereas 49L shows an 1803 problem. The specific tables within the Nautical Almanacs of 1796 and 1803 required to solve the problems shown on pages $44 \mathrm{~L}$ and $49 \mathrm{~L}$ in the Carter cipher book are Tables II (the sun's declination), III (the sun's semidiameter), VIII (the moon's semidiameter and horizontal parallax), and Tables VIII, IX, X and XI (angular distances between certain celestial bodies).

107 E-mail exchange with John Bidwell, 10 January 2014.

108 Leslie Morris, interview 20 November 2013.

109 Carter, Navigation Book, 2R.

110 John Hamilton Moore, The New Practical Navigator, 13 ${ }^{\text {th }}$ edition (London, 1798). The leading reference work for navigation training (including astronomical tables required for navigation at sea) in the English-speaking world at the end of the eighteenth and early nineteenth centuries. 
I did all I could to improve my learning; but not having many books, and for want of means to buy paper, pens, and ink, my progress was not very rapid, but I did with much pains and self-denial get on pretty well in arithmetic. I then began to learn navigation; having but one old Hamilton Moore's "Treatise" amongst us, I was obliged to copy out all the tables in that book before I could proceed with my learning. ${ }^{111}$

\section{William Carter Works a Lunar Observation to Find Longitude}

William Carter transcribed eight longitude problems, or "cases," in his prison school cipher book. Five were taken directly from his John Hamilton Moore textbook. ${ }^{112}$ The origins of the other three are not known. Given the formatting and mathematical differences between his work and the solutions printed in the textbook, it appears that Carter did not have direct access to the example solutions in Moore when he solved the problems. He did so under examination conditions.

The five cases taken from the textbook all state that the observations provided were taken in 1796. The three of unknown origin all use 1803 as the case year. Whether these three 1803 cases came from a different textbook or perhaps were created by an instructor is not known. In order to solve these eight cases Carter required three sets of tables that would have been found in three documents: Moore's New Practical Navigator, and The Nautical Almanacs for 1796 (for the first five) and for 1803 (for the last three).

The mathematical process he undertook to work his longitude problems is referred to as "clearing the distance." In Carter's time British mathematicians had developed at least five methods for clearing the distance. ${ }^{113}$ These methods were techniques used to calculate the corrections required to reconcile observed angular distances of interest with the actual distances.

By examination of the mathematical steps Carter took, it appears that Moore's text taught an approximate method of clearing the distance largely based on a technique developed by a brilliant British mathematician named Israel Lyons (1739-1775). Lyons was born and educated in Cambridge, and for some time taught at Oxford. However, he spent most of his professional life working for the government, specifically the Commissioners of Longitude, earning $£ 100$ per year in this capacity. The commission had been established by the same act of Parliament that created the Longitude Prize in 1715. It was a committee of experts tasked with judging submissions for the prize, as well as more broadly encouraging, and some cases undertaking, the search for a way to

111 Carter, Navigation Book, 2R, and Short, Prisoners of War In France, 76. It is worth noting that all of the tables in Moore amount to nearly 150 pages of dense data. Copying out "all of the tables" would have been a huge task and any hand copy very probably full of errors. Perhaps what Williams did was to copy the data from Moore specifically required to solve the navigation problems Williams was addressing.

112 Moore, The New Practical Navigator, 243-247, and 250-252.

113 Charles Cotter, A History of Nautical Astronomy (London, 1968), 208. They included Maskelyne (1763), Lyons (1767), Witchel (1772), Dunthorne (1772) and Moore himself (1775). Each seems to have borrowed heavily from the other. 
find longitude at sea. ${ }^{114}$ Lyons published his method in the first Nautical Almanac in 1767. The Nautical Almanac was a government publication. The government's Commissioners of Longitude at one time awarded him a prize of $£ 50$ for publishing his method. ${ }^{115}$

The first edition of Moore's Practical Navigator included instructions on only the most rudimentary methods of clearing the distance in lunar observations. ${ }^{116}$ In a paper published in 1775, Moore described a clearance method that he based on Lyons, and although at the time Moore gave no credit to Lyons other than mentioning that the method he used had been published in The Nautical Almanac. By 1800, Moore, in his thirteenth edition, credits "Dunthorne, Lyons, Witchel, \&c." as well as improvements on these methods made by "Maskelyne, Croswell, \&c." 117 In 1775 Moore wrote:

Many methods for finding the longitude by celestial observation have been proposed and successfully practiced on

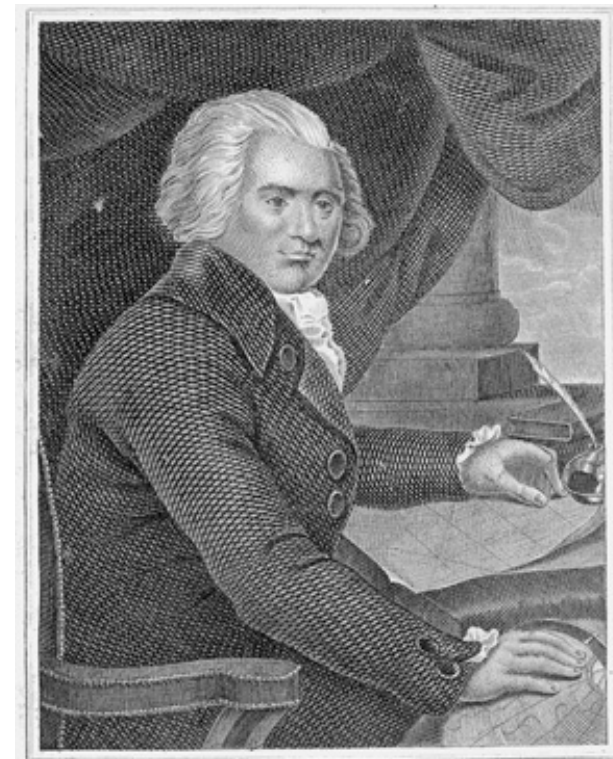

JoHN HAMILTON MOORE.

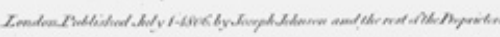

Figure 6: John Hamilton Moore in 1803. The Practical Navigator, 16th Edition. Frontispiece. land; but none has been found so convenient at sea, as that of observing the moon's distance from the sun, or a fixed star; both on account of the shortness of the moon's period, and consequently her quick progress in her orbit, and also on account of her being almost constantly conspicuous, and capable of being observed. ${ }^{118}$ The Royal Navy agreed, and establishing longitude by "lunars" dominated celestial navigation through the eighteenth and into the nineteenth century. ${ }^{119}$

To begin solving his lunars problem, Carter would have had at least a cursory

114 Great Britain, Acts of Parliament, 13 Anne c. 14.

115 Cotter, A History of Nautical Astronomy, 225.

116 John Hamilton Moore, The Practical Navigator and Seaman's Daily Assistant (London, 1772). Moore's Practical Navigator ran through eighteen editions while he was alive. The nineteenth was printed in 1814 under the auspices of Joseph Dessiou (John Hamilton Moore, The New Practical Navigator (Webyridge [sic], 1814)).

117 Moore, The New Practical Navigator (13 th Edition), 214.

118 Moore, "The Practical Observer," 21. Note that navigators routinely referred to the moon and stars as "her," while the sun was routinely "him."

119 By 1814, in Moore's nineteenth edition, his successor specifically states that the method employed to clear the distance is "Mr. Lyon's Method." See John Hamilton Moore, The New Practical Navigator (19 $9^{\text {th }}$ ed., 1814), 229. 


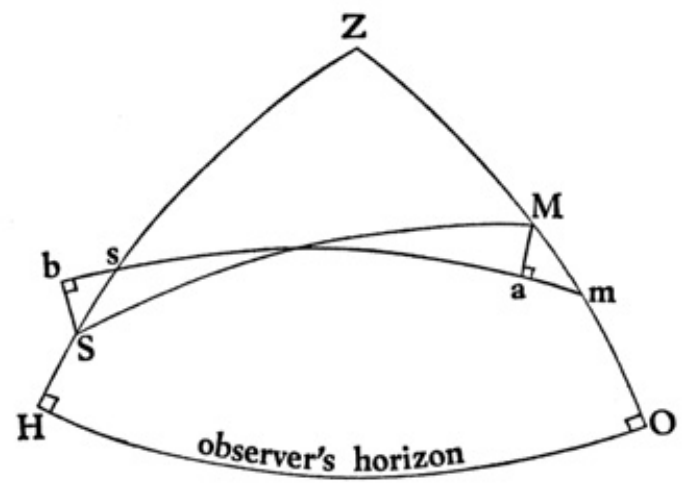

Figure 7: Celestial trigonometric construct. Cotter, A History of Nautical Astronomy, 225. understanding of the construct shown in figure 7. H-O represents the observer's horizon, and $\mathrm{Z}$ is the zenith directly over his head. $S$ is the exact position of a star (or Sun) corrected from its observed position using a sextant (s) and $\mathrm{M}$ is the exact position of the moon, also corrected from its observed position (m). What Carter needed to know is the exact arc distance between $\mathrm{M}$ and $\mathrm{S}$, or in other words, the angle MZS. If he knew this with precision, using his tables he would know exactly what time it was in Greenwich, England.

The following traces how Carter solved one of his eight "lunars." The problem and his work are shown on page $44 \mathrm{~L}$ of his cipher book, reproduced here as figure 8 , and is transcribed by the author in figure 9 .

Carter followed the step-by-step instructions on pages 239-242 of his Moore textbook to solve this spherical geometry problem. In so doing he would have referred to tables in the Nautical Almanac and in the back of his textbook twenty-three times, and he would have completed an equal number of addition or subtraction computations. (Therefore Carter had at least forty-six opportunities to make errors that could impact his result.) All twenty three computations for this problem are in his cipher book and therefore subject to review by his instructor or examiner.

The case in the cipher book assumes that a competent observer had already measured the angular distances of a crescent moon above the horizon, and the same for the common navigation star Regulus, as well as the angular distance between the two. The problem Carter had to solve was "clearing the distance" using these observed results.

Referring to figure 9 below, in the section marked " $A$ " he used his reckoned longitude to estimate the time at Greenwich to begin his process. The purpose of all of the calculations that follow was to correct, or "reduce" his estimated time to arrive at an actual time, thereby enabling him to derive his longitude. In " $\mathrm{B}$ " he transformed the observed angular altitude of the moon (provided in the problem) into a corrected altitude accounting for variables like his height above the water (also provided) and the crescent shape of the moon when what he needed was its center. Correcting for seemingly small variables such as "height of eye" are enormously important in precise celestial navigation. In " $C$ " he did the same for his star, in this case Regulus. In " $D$ " he corrected the observed distance between the crescent moon and star.

So with the completion of "B"-" $D$ " he now was ready to work out his angles. In "E" through "I" Carter used logarithm tables to calculate the arc of four angles that are required to establish the distance between $\mathrm{M}$ and $\mathrm{S}$, thereby deriving the value of the angle MZS shown in figure 7. After one further correction, it turns out that MZS is $63^{\circ} 04^{\prime} 32^{\prime}$ as shown at the top of section "J." Within section "J" he used an 


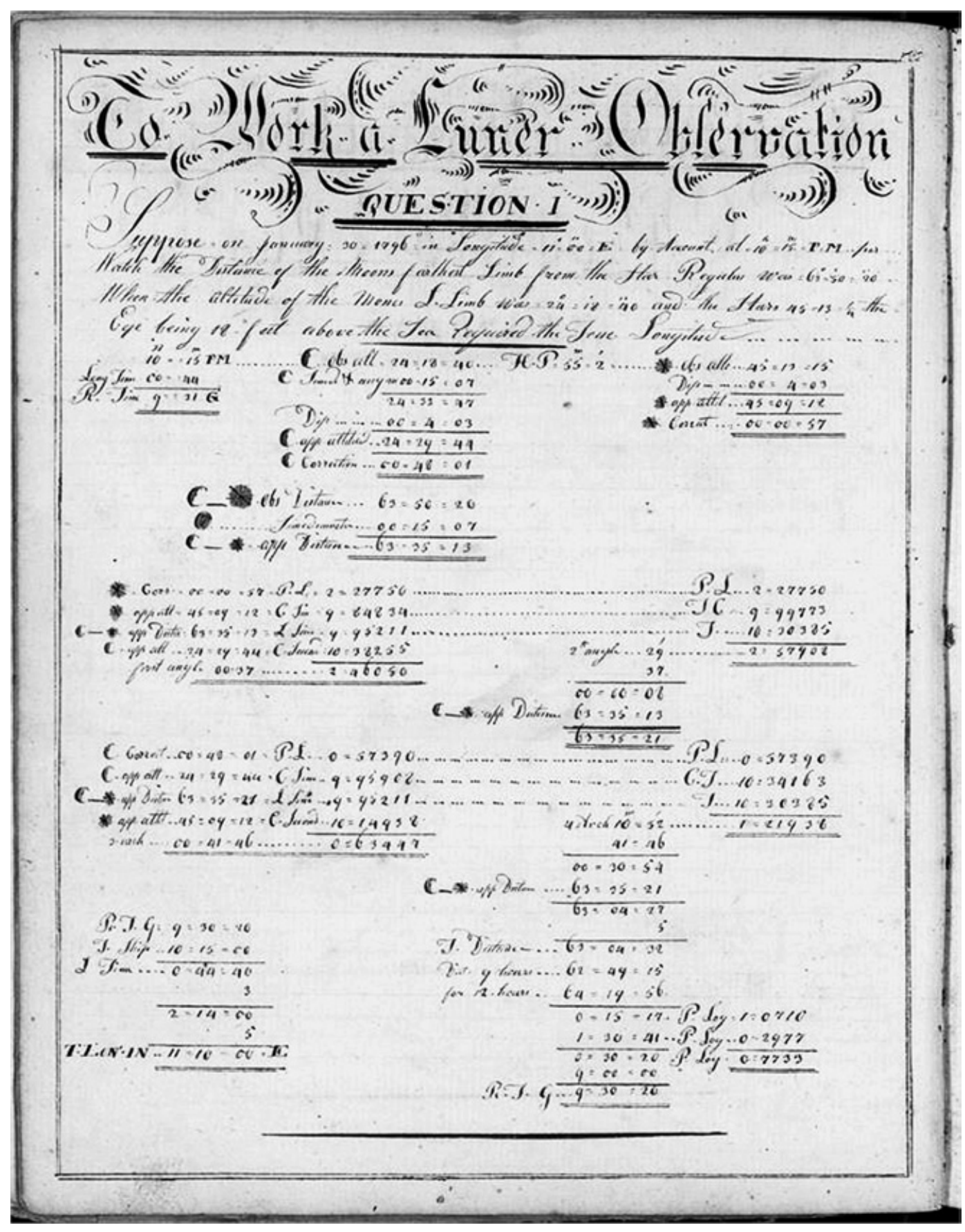

Figure 8: An example longitude problem using lunar observations. Carter, Navigation Book, $44 L$. 


\section{To Work a Lunar Observation}

Question 1

$$
\text { h } \mathrm{m}
$$

Suppose on January 301796 in Longitude $11^{\circ} 00^{\circ} \mathrm{E}$ by Account at 1015 PM per Watch the Distance of the Moons farthest Limb from the star Reglus was 630 50' $20^{\circ}$ When the altitude of the Moons L. Limb was $24^{\circ} 18^{\prime} 40^{\prime \prime}$ and the Stars $45^{\circ} 13^{\prime} 1 / 4$ the Eye being 18 feet above the Sea. Required the True Longitude

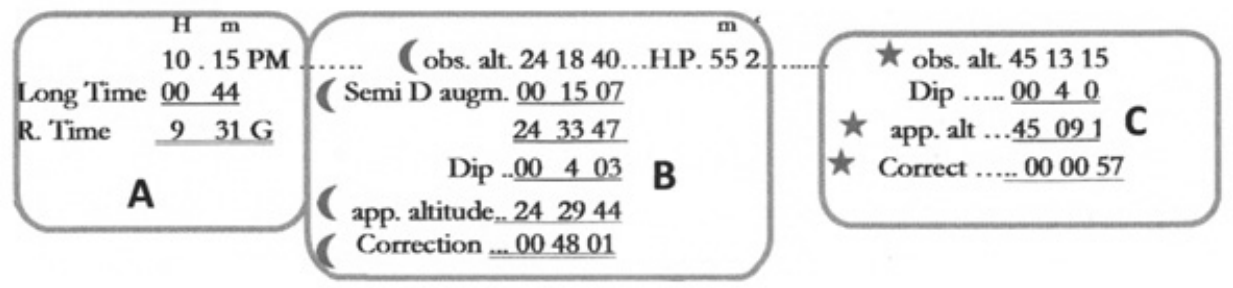

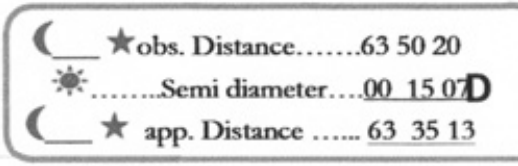

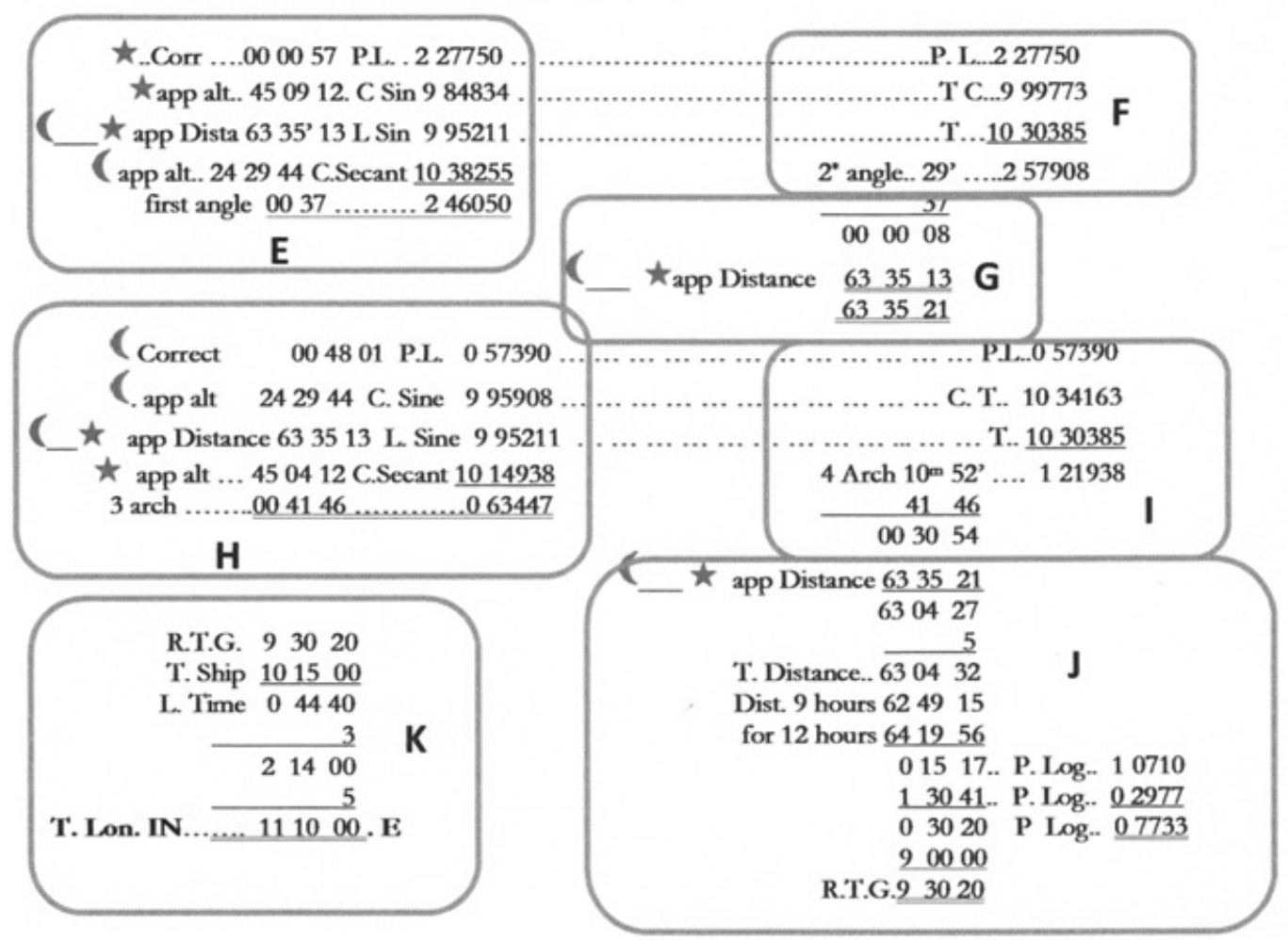

Figure 9: An example longitude problem using lunar observations. Transcribed and annotated by the author. Carter, Navigation Book, 44L (opposite). 
interpolation of the time tables in the Nautical Almanac to arrive at an exact "Reduced Time Greenwich," or "R.T.G." which has a value of 9 hours, 30 minutes and 20 seconds, or 40 seconds earlier than his reckoned time of 9 hours 31 minutes and zero seconds as shown in section "A." His final step was to transform that R.T.G. back into longitude using a common method shown in section $\mathrm{K}$. The answer is $11^{\circ} 10^{\prime} 0^{\prime \prime} \mathrm{E}$.

By working his lunar observations, Carter found that his imaginary ship was located $11^{\circ} 10^{\prime}$ east of the Greenwich meridian, as opposed to $11^{\circ}$ east as originally estimated in the statement of the problem. If we suppose that his ship is sailing in a latitude of $38^{\circ} \mathrm{N}$ (which with a longitude of $11^{\circ} \mathrm{E}$ places the ship somewhere between Corsica and Sicily in the central Mediterranean), by his observations and calculations Carter would have found that the ship was nearly eight nautical miles farther east than originally assumed. In the dark, near an unfamiliar coast, an eight-mile error could be fatal to a ship and her company.

William Carter then went on to solve the same problem using a simpler, but less precise method developed by George Witchel. ${ }^{120}$ His results were the same. Witchel's method required only seventeen calculations, and a similar number of trips to the tables, thereby reducing the chances of error. He then went on to solve seven more longitude problems; once using Lyons, then using Witchel.

\section{Consequences}

The creation and operation of the school for POWs at Givet prison was a significant achievement by the founders, as well as the prisoner tutors and students. It is interesting to the historian because it was an early example of how motivated and wellintentioned individuals like Captain Jahleel Brenton and Reverend Robert B. Wolfe could arrange and then operate a program that produced an informative artifact like the William Carter cipher book. The bulk of this paper is devoted to exploring the historical questions raised by that book: What were the circumstances at Givet when this artifact was created? How was it made? Who created it? What does it tell us about early nineteenthcentury navigation, and navigation training? There is ample evidence, however, that the Givet POW school did more than produce a provocative document.

First, it met Wolfe's and Brenton's objective of easing the hardship the sailors imprisoned at Givet had to endure for the nearly eleven years they were there. They were held with no hope of parole, and little hope of escape. The conditions were harsh, their health was bad, and they were very likely bored out of their minds. The Givet school was a relief. Fraser noted:

Through Brenton's instrumentality a school was opened to carry on the instruction of the midshipmen prisoners at Verdun, as at sea, in navigation and theoretical seamanship, so that when their time of liberation came they might be ready to qualify for promotion. By that means it was further hoped, incidentally, to occupy their minds and keep the lads from getting into trouble through having too much idle time. ${ }^{121}$

120 Carter, Navigation Book, 44R.

121 Fraser, Napoleon the Gaoler, 48. 
Wolfe himself wrote:

The immediate results, arising from this employment of their time, were beneficial, in a degree, at least equal to the professional advantages, which they might hope to experience in their future prospects. While they were thus receiving instruction and edification, their thoughts were diverted from dwelling upon those misfortunes, which had the most pernicious effect and influence upon their minds, not only in a moral and religious point of view, but, often, as it regarded their health and spirits. ${ }^{122}$

The school at Givet was above all, however, a vocational school. The curriculum did encompass reading, writing, and arithmetic, and these subjects were taught to the illiterate or dyscalculiate. For those who came to Givet able to read, write, and calculate (like William Carter), the vocational advantages conferred by the Givet school were far more important. The most prominent examples of post-war vocational success we have in the memoirs is that of John Tregerthen Short who learned to teach navigation while at Givet, and then returned to his home in Cornwall to continue his trade.

According to their memoirs (edited and introduced by Sir Edward Hain), both Short and his co-memoirist Thomas Williams hailed from St. Ives in Cornwall, in the extreme southwest of England. ${ }^{123}$ Hain described their capture by the French:

The Channel swarmed with swift and daring French privateers...in spite of the never-ceasing vigilance of British cruisers, the seizure of English merchant vessels was almost of daily occurrence....This was the fate which befell the crew of the FRIENDSHIP, who numbered seven in all - viz., Josias Sincock, master, who afterwards died a prisoner of war at Verdun; George Dunn, mate; Thomas Cougar, A.B., who died in the prison at Givet; the three apprentices who were cousins and nephews of Captain Sincock $3 / 4$ viz., John Tregerthen Short, nineteen years of age; Thomas Williams, seventeen; with William Sincock, son of the Captain, a boy of twelve. ${ }^{124}$

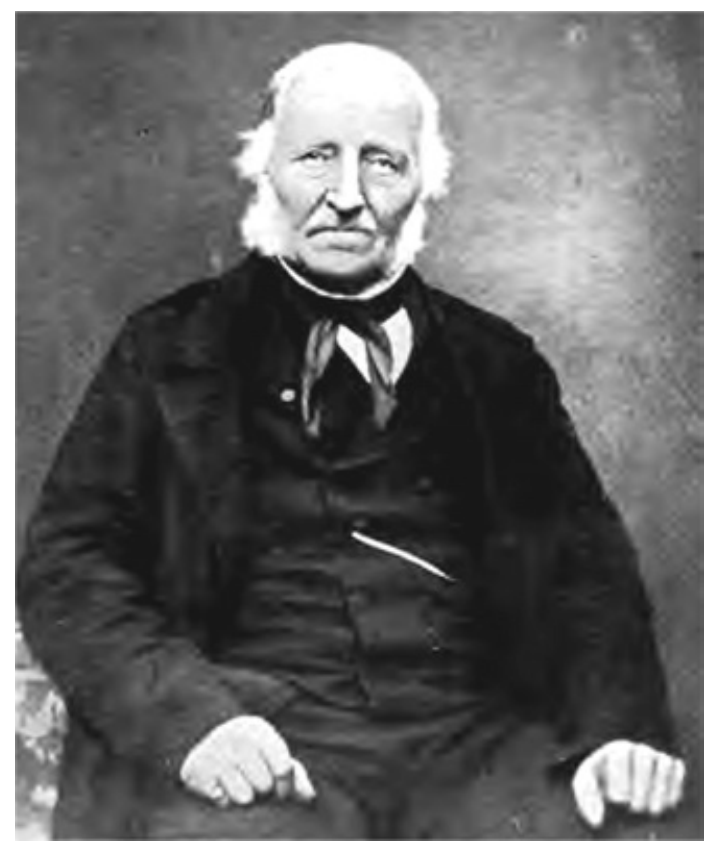

Figure 10: John T. Short circa 1860. Short, Prisoners of War in France, 25.

122 Wolfe, English Prisoners in France, 76.

123 Short, Prisoners of War in France, in the Introduction by Sir Edward Hain, 1.

124 Ibid., 2. 
Short and Williams were marched off to Givet, arriving there shortly after the men out of Minerve. By December 1805, Captain Brenton and the Reverend Wolfe had established their school, and Short and Williams both became involved. In the introduction to Short and Williams' memoir, Hain wrote:

Schools were also established, and between four and five hundred men were taught to read and write, besides arithmetic and navigation in all its branches. Mr. Short became a teacher, and here acquired that knowledge of navigation which was to prove so valuable to him in after-life, when he established the Navigation School at St. Ives, famous in its day amongst West-Country sailors. ${ }^{125}$

Short's cousin Thomas Williams made several attempts as escape, failing each time. Short gave no evidence of attempting to escape, and spent his time working and tutoring in the prison school. When the war finally ended, the English prisoners were marched to the coast and transported home to England. Short and Williams arrived in St. Ives in May 1814 having spent nearly ten years at Givet. ${ }^{126}$

Apparently Mr. Short's navigation school at St. Ives thrived, and continued operating for some time (date not known) after his death in 1873 . The photograph shown in figure 11 is undated, but may have been taken as late as 1914 when Sir Edward wrote his introduction. It was still referred to as "The Old Navigation School." Mr. Short's navigation school building still stands in St. Ives - it is privately owned and is leased as vacation rental cottages. $^{127}$

Wolfe has left evidence that other students and tutors at the Givet school brought their useful skills back to England. The last sentences in his memoirs are testimonials to what he considered the greatest achievement of his ministry at Givet:

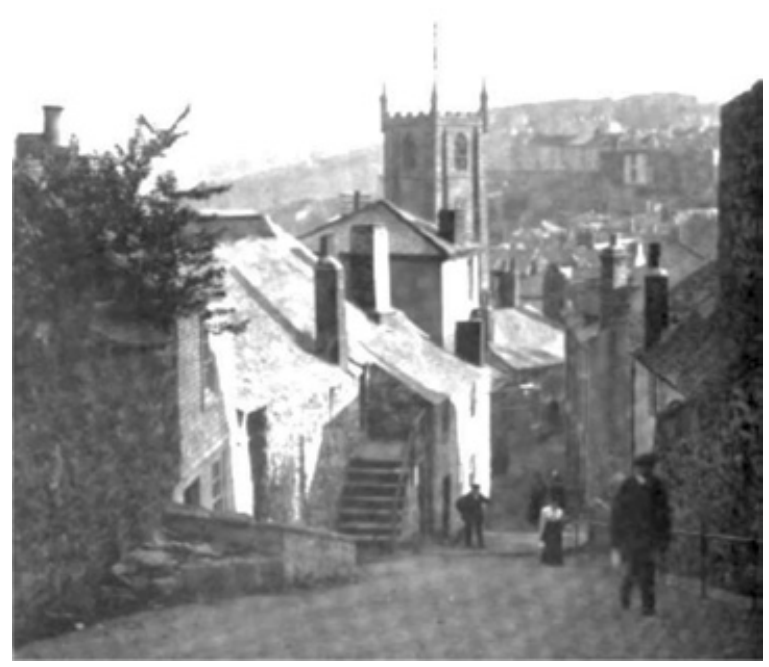

Figure 11: The "Old Navigation School, St. Ives." Short, Prisoners of War in France, 257.

For some of our poor fellows I have been able to procure situations in this country, which their instruction in Givet rendered them capable of; and to which their good conduct, during the period of their imprisonment, recommended them. And I have

125 Short, Prisoners of War in France, 10.

126 "January 8, 1865. - This morning, fifty-one years ago, I, with 150 others, left the depot prison of Givet in France, where I had been confined as a prisoner of war for nine years and nine months." Short's recollection, Prisoners of War in France, 331.

127 Academy Cottage, St. Ives, Cornwall, http://www.academycottagestives.co.uk/about.html. Accessed 15 January 2014. 
been informed of many, who are now occupying stations exceedingly superior to their original prospects in life; having been taught, even to read, during their captivity as prisoners of war in France. ${ }^{128}$

The navigation problem solving techniques taught at Givet, in particular the measurement of a ship's longitude at sea by lunar distance methods, were intellectually challenging, but also highly relevant. Lunar methods were included in the Royal Naval College curriculum in the early nineteenth century, and in fact persisted in formal navigation training programs in the private sector until at least 1840. ${ }^{129}$ Captain James Cook's last voyage in 1773 had proven that John Harrison's "Timekeeper" was a useful and practical tool for measuring local vs. Greenwich time, and therefore enabled a simplified method of establishing longitude at sea. However, the lunar method persisted aboard ship, including within Great Britain's merchant marine. The question is "Why"?

The author reviewed three log books preserved at the Mystic Seaport G.W. Blunt Library in Mystic, Connecticut. The first is from the East India Company's HCS [Honorable Company's Ship] Charles Grant of Portsmouth, England. Under the command of John Lock, Esq., Charles Grant departed Gravesend, London on 1 December 1812, as part of a convoy to China. ${ }^{130}$ She was escorted by HMS Venus (36), a fifth rate frigate captured from the Danes in 1807. ${ }^{131}$ She was accompanied by five other merchantmen, so the fleet totaled seven vessels. The log shows that latitude was "observed" each day the ship was underway. However, no longitude recordings appear, regardless of method, until day 6 when presumably the convoy was out of sight of land. That observation was made "per chr.," that is, by using the ship's chronometer. In days 7-13, there are no longitude entries. On day 14 of the voyage, another "per chr." longitude was entered. Finally on Sunday, 24 January 1813, after nearly two months at sea, the logbook entry shows "Longitude obs'd per Sun \& Moon $17^{\circ} 13^{\prime} 6^{\prime \prime} . "$ More commonly, the log shows an entry indicating that a "Mean Fleet Longitude" was used. This suggests that some or all of the ships in the convoy signaled their observed longitude (methods unknown) on those particular days (approximately once per week on this particular voyage) and the navigator aboard the HCS Charles Grant calculated the mean of all of those observations and entered that position in his log. "Mean Fleet Longitude" was an interesting, and likely effective, method of improving positional accuracy for a convoy at sea.

In the second log, HCS Lord Lowther of London, Robert Fowler, Esq. Commander (a young twenty-nine years old, according to the muster entries) departed

128 Wolfe, English Prisoners in France, 168.

129 William Thompson, "Notebook. Cromer School, England," [1839], Misc Vols. 6-10, G.W. Blunt Library, Mystic Seaport, Mystic, CT.

130 “Logbook of CHARLES GRANT of Portsmouth,” Log \#132, 1812-1813, G.W. Blunt Library, Mystic Seaport.

131 Royal Museums Greenwich, http://www.rmg.co.uk/upload/pdf/Warship_Histories_Vessels _v.pdf. 1812. Accessed 6 March 2014. 
London on Tuesday, 27 April 1830. ${ }^{132}$ Her log was maintained by Robert Jaques, $4^{\text {th }}$ Officer. She had 146 men aboard (15 of whom died on the voyage) and she too, was bound for China. HCS Lord Lowther was owned by the Honourable East India Company (HEIC). Her logbook is more formal and comprehensive than the privately owned HCS Charles Grant. The log shows latitude established "by observation" each day (except when in or near port), and longitude established by chronometer most days she was at sea. In addition, perhaps due to HEIS regulations or the convention of the day, longitude also was established by lunars on days 24 and each day 29-33. It appears that the navigators aboard HCS Lord Lowther used lunars to ensure that their chronometers were keeping accurate time.

In the third log, HCS Orestes departed Bristol bound for Madras, India, and ports beyond on 28 February 1836. ${ }^{133}$ Per chronometer longitudes were entered regularly. Lunar-based longitudes were entered in the $\log$ on days 28,40 , and 83 and she arrived Madras on 28 May 1836. One such entry is shown here:

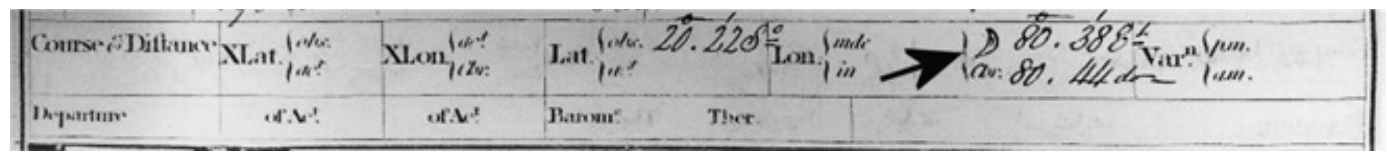

Figure 12. Log entry showing longitude determination using the lunar method, written in above the finding by chronometer. Highlight by this author. Logbook of ORESTES, Mystic Seaport Museum.

Orestes then departed Madras on 5 June 1836, and arrived in Calcutta on 10 June 1836. No longitudes were entered on this short leg. She departed Calcutta on 1 August 1836, and arrived Singapore on Tuesday, 30 August 1836. Again, no longitudes were entered. It appears that aboard HCS Orestes (like HCS Lord Lowther), lunars were used every third week or so on long passages to check the accuracy of the per chronometer measurements. Whether this procedure was an East India Company requirement or the inclination of the ships' officers is not known.

These three merchantmen logs show that William Carter and his fellow navigation students at Givet prison were taught methods that were not only complex and advanced but highly relevant to a vocational future in Britain's post-war merchant marine. John Tregerthen Short claimed to have learned these techniques at Givet and was then able to integrate them into his curriculum at his post-war navigation school at St. Ives. His vocational advantage is clear. We do not know what happened to William Carter after he wrote his cipher book. However, based on the indirect evidence in the Brenton, Wolfe, and Short memoirs, we can imagine his outcome. If he survived prison, he could have returned to his probable home in Cornwall. He would have been able to present himself in the office of a merchant firm, or more likely, to an officer of a merchantman like the HCS Charles Grant,

132 “Logbook of LORD LOWTHER of London,” Log \#162, 1830, G.W. Blunt Library, Mystic Seaport.

133 “Logbook of ORESTES of Bristol,” Log \#137, 1836, ibid. 
Lord Lowther, or Orestes. His resumé would have encompassed substantial sea time aboard at least two royal naval warships as well as demonstrated competence in reading, writing, arithmetic, draftsmanship, and, above all, navigation problemsolving skills, including an ability to establish longitude by use of several lunar distance methods, a capability that remained important for navigators in Britain's merchant marine until at least 1839. If he had been able to salvage his cipher book from the Givet POW school in his chaotic departure from France, he also would have had written evidence of his capabilities. His future as a merchant sailor would have been assured. 
